This is a self-archived - parallel published version of this article in the publication archive of the University of Vaasa. It might differ from the original.

\title{
Organizing the Exploitation of Vulnerable People: A Qualitative Assessment of Human Trafficking
}

Author(s): Shepherd, Dean A.; Parida, Vinit; Williams, Trent; Wincent, Joakim

Title: $\quad$ Organizing the Exploitation of Vulnerable People: A Qualitative Assessment of Human Trafficking

Year: $\quad 2021$

Version: Accepted manuscript

Copyright (C)2021 SAGE Publications. The article is protected by copyright and reuse is restricted to non-commercial and no derivative uses. Users may also download and save a local copy of an article accessed in an institutional repository for the user's personal reference. Shepherd, Dean A., Parida, Vinit, Williams, Trent \& Wincent, Joakim: Organizing the Exploitation of Vulnerable People: A Qualitative Assessment of Human Trafficking. Journal of Management. Copyright (C) [2021] SAGE Publications. DOI: 10.1177/01492063211046908.

\section{Please cite the original version:}

Shepherd, D. A., Parida, V., Williams, T. \& Wincent, J. (2021). Organizing the Exploitation of Vulnerable People: A Qualitative Assessment of Human Trafficking. Journal of Management. https://doi.org/10.1177/01492063211046908 


\title{
ORGANIZING THE EXPLOITATION OF VULNERABLE PEOPLE: A QUALITATIVE ASSESSMENT OF HUMAN TRAFFICKING ${ }^{*}$
}

\author{
DEAN A. SHEPHERD \\ University of Notre Dame \\ Mendoza College of Business \\ Notre Dame, IN \\ dshepherd@indiana.edu \\ VINIT PARIDA \\ Luleå University of Technology \\ Department of Business Administration, Technology and Social Sciences \\ Lulea, Sweden \\ vinit.parida@ltu.se \\ and \\ University of Vaasa \\ School of Management \\ Vaasa, Finland \\ TRENT WILLIAMS \\ Indiana University \\ Department of Management and Entrepreneurship \\ trenwill@iu.edu \\ JOAKIM WINCENT \\ Hanken School of Economics \\ Helsinki, Fi \\ joakim.wincent@hanken.fi \\ and \\ University of St Gallen \\ St Gallen, Ch \\ Joakim.wincent@unisg.ch
}

Authors' Version. Please cite as:

Shepherd, D.A., Parida, V, Williams, T. and Wincent, J. (in press). Organizing the exploitation of vulnerable people: A qualitative assessment of human trafficking. Journal of Management, forthcoming.

\footnotetext{
${ }^{*}$ We would like to thank three anonymous reviewers and Ali Ferguson.
} 


\begin{abstract}
Focusing on the organizing practices by which vulnerable individuals are exploited for their labor, we build a model that depicts how human traffickers systematically target impoverished girls and women and transform their autonomous objection into unquestioned compliance. Drawing from qualitative interviews with women forced into labor in the sex industry, human traffickers, brothel managers, and other sources (e.g., doctors, non-government organizations, and police officers fighting human trafficking), we inductively theorize that organizing of vulnerable individuals for human exploitation involves four inter-related practices- (1) deceptive recruiting of the vulnerable, (2) entrapping through isolation, (3) extinguishing alternatives by building barriers, and (4) converting the exploited into exploiters - that together erode and eventually eliminate workers' autonomy. We conclude by discussing implications of our research for theory—specifically, the literature on human exploitation and loss of worker agency.
\end{abstract}

Keywords: Deviant/Counterproductive Behavior, Power and Politics, Grounded Theory, Conflict Management. 


\section{ORGANIZING THE EXPLOITATION OF VULNERABLE PEOPLE: A QUALITATIVE ASSESSMENT OF HUMAN TRAFFICKING}

The girls that are forced into the sex trade at 13 are really locked in. They start off in a real prison, which then becomes a psychological cage, so that they are scared to step outside of the confines of that. It's heartbreaking. (Archival transcript from a nongovernmental organization)

Some organizations engage in human exploitation practices that diminish and sacrifice workers' well-being to generate economic firm profits. As an illustration, the International Labour Organization (ILO) estimates that more than 20.9 million people around the world are forced into labor through coercion and deception and are unable to leave and that this form of labor generates more than $\$ 150$ billion in annual profits (ILO, 2012). The exploitation of workers occurs in many forms and to varying degrees, including discrimination in hiring practices (Mobasseri, 2019), under-payment of immigrant labor (Catron, 2019; Wilson \& Portes, 1980), and the creation and persistence of sweatshops (Gordon, 2005). In addition, worker exploitation occurs across a wide range of industries, including agriculture, construction, domestic work, manufacturing, and military service (ILO, 2012). As an extreme form of labor exploitation, modern slavery involves "situations of exploitation that a person cannot refuse or leave because of threats, violence, coercion, deception, or abuse of power" (Crane et al., 2021: 1). Despite the illegality of modern slavery and human trafficking, the problem persists as tens of millions of people endure exploitation at the hands of organized traffickers each year-with estimates that one in four are children (ILO.org).

Management scholars have responded to labor exploitation largely by taking the perspective of established organizations and exploring the risks they might face should one of their suppliers be caught exploiting vulnerable people's labor. For example, research has 
explored the damage this discovery can make on an organization's public reputation (Chen \& Lee, 2017) and stakeholder relationships (Hofmann et al., 2014). Specifically, management research has focused on social responsibility strategies (Caruana et al., 2021; Crane et al., 2021; Maignan, Hillebrand \& McAlister, 2002), supplier inspections and penalty schemes (Kolk \& van Tulder, 2002; Plambeck \& Taylor, 2016), and other forms of supply chain management (Crane et al., 2019; Kim, Wagner \& Colicchia, 2019; LeBaron, 2020) to manage these potential negative consequences of labor exploitation. In contrast to those up the supply chain, Crane and colleagues (2021) note that insufficient scholarly attention has been paid to the supply chains of firms engaged in modern slavery - that is, organizations directly involved in perpetuating slavery (Phung, 2018). Although we have learned about some of the practices of modern slavery (e.g., debt bondage [Bales, 2004; Friebel \& Guriev, 2006; LeBaron, 2014]) and human trafficking (e.g., trauma-bond recruiting [Dorais \& Corriveau, 2009; Reid \& Jones, 2011]), we lack a cohesive view of how actors organize the exploitation of vulnerable people's labor.

Addressing the lack of knowledge on organizing that exploits vulnerable people is increasingly important. Indeed, the problem of human trafficking and the organization of exploiting vulnerable people are global in scale, with the US State Department recently identifying more than 46 countries as failing to systematically address human exploitation (State.gov; see also Global Report on Trafficking in Person, 2018). Similarly, management theories exploring how organizations address socio-cultural problems (i.e., corporate social responsibility, social entrepreneurship, etc.) do not adequately address explicit organizational efforts of exploiting the vulnerable. Therefore, we seek to address the following question: How is exploitation of the vulnerable organized such that people join and continue working under harsh working conditions against their will? 
To address this research question, we employ an inductive research design following Weitzer's (2014) call for more qualitative research to develop richer insights into the lived experiences of people who have been trafficked and exploited for their labor. Our research context is organizations that coerce and retain girls and women against their will into the sex industry in and near Mumbai, India. Separate from research on sex trafficking, we believe that it is essential to understand how perpetrators organize to exploit vulnerable people because understanding the how is necessary to provide new insights into counter-organizing to eliminate such practices_-including government policy, non-governmental organization (NGO) interventions, and so forth.

The primary contribution of our inductive study for the management literature is a grounded theoretical model of what we call organizing to exploit the vulnerable, which we define as actors' deliberate processes of inter-related structures and practices to diminish individuals' autonomy and unfairly use their labor for their own (i.e., the exploiters') financial gain. We use the label "organizing" to reflect our interest in the processes of action and the changing nature of the (potential) workers rather than the organizational entity (consistent with Chia, 1999; Tsoukas \& Chia, 2002; Van de Ven \& Poole, 2005; Weick, 1979). Our findings and grounded theorizing provide an important foray into lived experiences of labor exploitation across different phases and exploiters and offer a management perspective for research on human exploitation. Further, to the sex trafficking literature, we add insights into the practices of recruiting and exploiting vulnerable people. In doing so, we hope to mobilize management scholarship that can begin the processes of unraveling exploitive labor at its roots. 


\section{THEORETICAL BACKGROUND}

\section{Human Exploitation}

The exploitation of labor from modern slavery often begins with human trafficking. Human trafficking refers to the non-consensual recruitment and/or movement of a person to exploit his or her labor (United Nations, 2000). Research on the phenomenon of human trafficking has primarily focused on the sex industry (Sweileh, 2018) and has been explored through multiple disciplinary lenses, including criminology (Farrell, 2009; Kenyon \& Schanz, 2014), sociology (Desyllas, 2007; Jordan, Patel \& Rapp, 2013), international studies (Aradau, 2004), and clinical health (Konrad et al., 2017; Miller, 2008; Zimmerman, Hossain \& Watts, 2011). This body of research has explored definitional and operationalization issues (Oram et al., 2011), the prevalence of the phenomenon (Farrell, McDevitt \& Fahy, 2010; Zimmerman \& Kiss, 2017), the push and pull antecedents (George \& Stanley, 2019; Shelley, 2010), and the negative consequences experienced by those who are exploited (Oram et al., 2016; Ottisova et al., 2016; Silverman et al., 2007). We conclude from these studies that trafficking is a form of modern slavery, "an acute intersection of vulnerability and exploitation" (Jones et al., 2007: 113).

There are reports about how actors recruit and retain vulnerable individuals for exploitation. For example, human sex traffickers first scout vulnerable recruits by targeting (primarily) girls and women in abusive homes or other types of harsh living conditions (Albanese, 2007). Then, traffickers seek to establish a trauma bond by promising love, attention, and/or safety as a (1) boyfriend/lover or (2) someone who can help them escape hardship (Dorais \& Corriveau, 2009; Reid \& Jones, 2011). The combined effect of prior trauma and sex traffickers' exploitative methods creates an emotionally entrapping connection (Reid, 2016). Despite the data gathered by governments and NGOs, we have a fragmented picture of how 
traffickers exploit vulnerable individuals due to the difficulty in detecting and documenting trafficking. Indeed, Kiss and Zimmerman (2019: 2) recommend that "serious consideration must be given to the structures and practices that enable exploitation and leave individuals with extremely limited ability to alter their circumstances."

Structures and practices are central to organizing. In applying the lens of organizing to human trafficking, we can better understand the structures and practices that initiate and perpetuate human exploitation. Organizing refers to the process of "how structure and actions inter-relate to accomplish organizationally relevant outcomes" (Dutton et al., 2006: 59; Weick, 1995). While there is management research on human trafficking and modern slavery from the perspectives of governance (LeBaron \& Lister, 2015; LeBaron, Lister \& Dauvergne, 2017), supply chain management (Crane et al., 2019; Kim et al., 2019; Konrad et al., 2017), and corporate social responsibility (Murphy, Clifford \& Vargas, 2019; Schrempf-Stirling, Palazzo \& Phillips, 2016), this research typically involves actors far removed from the lived experiences of human trafficking and labor exploitation (van Buren, Schrempf-Stirling \& Westermann-Behaylo, 2021). An exploration of how traffickers organize (i.e., structures and activities) to exploit labor provides an opportunity for increased understanding of the business of exploitation, the reasons some traffickers are more successful at recruiting and exploiting vulnerable people than other traffickers, and — hopefully—more effective interventions to obstruct this exploitation.

\section{Social Cognitive Theory and Loss of Agency}

Social cognitive theory (Bandura, 1989, 2001) is a theory of agency that focuses on the dynamic interplay between the environment and a person's behavior, suggesting that some degree of control over one's life is the essence of humanness (Bandura, 2001: 1). That is, social cognitive theory argues that individuals are neither completely autonomous nor "simply 
mechanical conveyors of animating environmental influences" but rather make causal agentic contributions to their own actions and motivations within a system of "triadic reciprocal causation" (Bandura, 1989: 1175). The model of triadic reciprocal causation involves the dynamic interplay of a person (e.g., cognitive and affective), a behavior (e.g., problem-focused coping), and an environment (Benight et al., 2018). This model also applies to the process by which individuals regain agency after it is lost due to a disruption or trauma (Benight et al., 2018).

Despite the promise of post-traumatic agency (Cieslak et al., 2009; Maitlis, 2009), trauma outcomes are often negative. As Benight and colleagues (2018: 4) note, "a subset of trauma survivors will reach a critical threshold when they believe it is just not possible to regain a sense of control over their recovery.” Benight and colleagues (2018) refer to this lack-of-control threshold as the self-determination violation effect. The consequences of this effect are negative emotional states driven by an agency crisis (Benight et al., 2018), perceived lack of ability to cope with the threatening situation, and feelings of reduced connection to others (Ryan \& Deci, 2000). The self-determination violation effect can lead to the opposite of autonomy - to controlled regulation (Ryan \& Deci, 2006: 1557). That is, when individuals are highly regulated, they perceive others as controlling their behavior, and they experience a loss of autonomy and self-determination (Deci et al., 2017: 21) — they feel dominated.

While the notion of the loss of agency has been explored in the psychology literature (for review, see Ryan \& Deci, 2017), the conversation often focuses on how individuals respond to ad hoc external influences that shape one's sense of lost agency rather than a systematic, organized effort by another to take it away. For example, Ryan and Deci (2017:77-78) provide an example of an individual who wants to quit smoking but then violates this internal goal: "after 
exposure to a cigarette ad, [he] find[s] himself mindlessly grasping for a smoke." As illustrated with this example, non-agentic behavior is often linked to habits and/or impulses that are reactionary and non-conscious when certain actions or attitudes are primed (e.g., by the cigarette ad). Indeed, loss of agency is said to occur when "the extent that one engages in an extrinsically motivated activity [is] wholly ... a function of external contingencies, or . . the extent that the value underlying an activity is not personally embraced" (Ryan and Deci, 2017: 69).

\section{Entrapment}

Feelings of lack of self-control result in individuals experiencing reduced self-motivation and reduced well-being as they perceive that their regulation is controlled by forces other than or alien to the self (Deci et al., 2017). If these perceptions persist over time, they eventually lead to a sense of entrapment. Entrapment refers to a sense that one is hemmed into a situation against his or her volition and, despite desiring to free oneself, is "tied with the perception that all escape routes are blocked" (Taylor et al., 2009: 795). Entrapped individuals perceive that escape is not possible, which then leads them to emphasize defensive behavior to reduce further damages from their entrapped situations (Gilbert \& Allan, 1998). Linking the entrapment scholarship to social cognitive theory, it could be argued that entrapped individuals experience a loss of autonomy in that they believe they are powerless to extract themselves from their hostile conditions (Quarantelli, 1954; Taylor et al., 2009).

Traditionally, scholarship on entrapment has focused on adverse social situations in which there is a power imbalance within societal roles. Somewhat surprisingly, with few exceptions (e.g., Haack et al., 2012; Weick \& Sutcliffe, 2003), scholarship on entrapment has focused primarily on personal relationships rather than formal organization-structured power imbalances (Brockner \& Rubin, 2012). For example, entrapment occurs for those prone to 
depression and arrested escape (entrapment) facilitates that depression (Gilbert \& Gilbert, 2003: 173), which is exacerbated by power differences in subordinate personal relationships, such as women in violent domestic relationships (Stark, 2009), battered women living lives of crime (Ritchie, 1996), and immigrants in the peripheral economy (Núñez \& Heyman, 2007). One common mechanism that enables entrapment is the use of trauma bonding by those in power (i.e., the entrappers) to maintain control over their victims (Reid, 2016). In trauma bonding, the entrapper elicits fear in the victim that is experienced as gratitude for being allowed to survive and avoid further abuse. Conditions for trauma bonding include a severe power imbalance, resulting in helplessness and dependency, and intermittent abuse interspersed with positive or neutral interactions (Dutton \& Painter, 1993; Mirowsky, 1985).

Entrapment can lead to mental defeat (Hazeldine-Baker et al., 2018) — that is, a state of giving up (Ehlers et al., 2000) and a "complete loss of inner resistance" (Wilker et al., 2017: 974). This mental defeat is associated with negative self-views (Kleim et al., 2012), maladaptive coping styles (Dunmore et al., 2001), and post-traumatic distress disorder (Ehlers et al., 2000; Wilker et al. 2017) and has been found in victims of sexual assault (Dunmore et al., 1997), tortured political prisoners (Duncan 1996), and other instances of involuntary subordination (Struman, 2011). While we know the tactics abusive individuals employ in personal relationships, we do not fully understand how entrapment and other mechanisms might be employed systematically through organizing processes. Furthermore, there is a need to better link the organizational processes of entrapment to eliminating autonomy, which has yet to be explored in the literature. 


\section{RESEARCH METHOD}

We employed a systematic qualitative data analysis to construct theoretical ideas on the basis of data (Timmermans \& Tavory, 2012) to examine how actors organize the exploitation of vulnerable individuals. Our objective was to theorize through inductive analysis (Bryant, 2002; Charmaz, 2006; Clarke, 2005). Specifically, the data for our theorizing included primary data collected from 56 respondents representing multiple sources (i.e., sex workers, human traffickers, brothel managers, NGO representatives, doctors, and police officers), from whom we sought to understand the lived experiences of girls and women engaged in the sex trade.

\section{General Context: Human Trafficking in the Sex Industry}

Human trafficking and modern slavery in the sex industry are grand challenges that are currently plaguing countries across the globe. While the exact number of individuals trafficked for exploitation is unknown due to the illegal nature of the activity (Weitzer, 2014; Zhang, 2009), a number of reports (Di Tommaso et al., 2009, ILO 2012; Weitzer, 2015) indicate that trafficking impacts millions of victims each year, suggesting that human trafficking in the sex industry is not rare (UNDOC.org, 2020). Furthermore, data (also affirmed by our informants) suggest that female victims are particularly affected by trafficking ( $70 \%$ of all victims detected are women or girls), and the vast majority of female victims (72\%) are trafficked for sexual exploitation - the remaining being trafficked for other forms of forced labor (UNDOC.org, 2020; see also Huda, 2006). Therefore, we focus on this group of vulnerable individuals. ${ }^{1}$ Prostitution of sex workers - the exchange of sexual services for money (Batsyukova, 2007) — is generally considered dirty work in that society views the prostitution occupation and related tasks as “disgusting or degrading” (Ashforth \& Kreiner, 1999: 413). On the face of it, prostitution is onerous work. First, women and others involved in prostitution are stigmatized (Ashforth \& 
Kreiner, 2014; Benoit et al., 2018), and this stigmatization seems to be strongest in the cultures of developing countries, in which the recruitment of girls and women is the greatest. Second, prostitution is dangerous work. Women engaged in prostitution are often physically and verbally assaulted by customers, employers, and others (Farley \& Barkan, 1998) and run a high risk of contracting sexually transmitted diseases, such as HIV (Gil et al., 1996). Finally, most places for prostitution in developing countries are located in large cities, which means that many girls and women from villages are moved to cities and thus experience social isolation and loneliness (Baker et al., 2010).

To address our research question about how actors exploit vulnerable girls and women in the sex industry, we sampled purposefully across four target groups: (1) current sex workers, (2) current human traffickers and brothel managers, (3) former sex workers (i.e., escaped from the career), and (4) those attempting to help current and former workers of this industry. All informants were from Kamathipura, India, Asia’s largest red-light district (Gezinski \& Karandikar, 2013). Because people in this area are wary of strangers (and thus unlikely to talk to strangers and perhaps become the victims of assault), we collaborated closely with local NGOs to collect data in a way that was respectful, comfortable for our informants, and most likely to allow informants to speak freely and openly about their experiences. The local NGOs we worked with focus on rehabilitating (e.g., developing skills for working outside the sex industry and coping with trauma) and providing medical support for active and former sex workers. In total, we collaborated with three local NGOs (i.e., Aadhar Trust, Sai, and Udaan) and one nationally recognized NGO (i.e., Freeset), who helped us access our informants and provided invaluable contextual knowledge. 
Having the support of local NGOs facilitated our access to relevant informants and enhanced the quality of our interviews - interviewees felt their information was safe with our team. Our data-collection team consisted of two of the four authors (with the exception that one of the other authors participated in one NGO interview) and three locals serving as guides. The three locals had experience in data collection, knew the local area and people, and were therefore essential in facilitating natural interactions with informants. NGO employees directed us to certain brothels in Kamathipura where sex workers would be most willing to talk about their life and profession. In many cases, a representative from the NGOs joined us during the interviews to build trust and ensure safety for the sex workers and us. The NGO representatives suggested that we interview six specific people — who we did interview — who had been active in the sex industry for a long time and who had extensive knowledge of sex worker exploitation and the trafficking process. We then interviewed additional individuals, combining insights from informants to develop a basic understanding of the human trafficking industry, including key roles, timelines for accessing and preparing workers, and mechanisms for retaining workers.

\section{Data Sources}

Data-collection methodology. Consistent with other qualitative studies, to give an authentic representation of people's lived experiences, our primary data source is semi-structured interviews (Eisenhardt, Graebner \& Sonenshein, 2016; e.g., Crosina \& Pratt, 2019; Eisenhardt, 1989; Gephart, 2004) conducted with 56 individuals. As the interviews focused on vulnerable groups of respondents, we used open-ended questions, avoided emotionally loaded words and phrases, and treated these individuals with care and respect. This approach reduced the possibility of social bias during data collection (Enclow \& Swisher, 1986; Larsson, 2018). We also gathered observational data to supplement and inform the interviews. Given this topic's 
emotional nature, we did our best to remain dispassionate in conducting our interviews (see Golden-Biddle \& Locke, 2007). To achieve a dispassionate, rigorous, and trustworthy datacollection process, we used the insider and outsider approach (consistent with Crosina and Pratt [2019]). The first author performed the outsider role, and the second author performed the insider role. The authorship team's insider is a native of India and is fluent in the local dialects and was well situated to manage the data-collection and translation processes. The insider provided the outsider updates on progress with the interviews and some of the challenges faced.

The outsider role (first author) involved the following. First, the outsider provided a check on the data-collection process. For example, the outsider ensured the insider did not ask leading questions, did not prematurely come to conclusions, and did not impart personal bias into the process. Second, the outsider played the role of devil's advocate, asking the insider for clarification (Strike \& Rerup, 2016). Third, the outsider also motivated the insider to persist with data-collection efforts and offered suggestions for overcoming data-collection obstacles as they arose. Fourth, the outsider facilitated the analysis of these data (as detailed below), identified themes, and generated preliminary models. Then, it was the insider's responsibility to request clarification and elaboration and ask critical questions based on knowledge of the phenomenon. Fifth, the other authors (the third and fourth authors) performed the role of outsiders with no connection to data collection. They reviewed the emerging model and delved between it and the data to push the original outsider and insider for clarification and explanation. Finally, while all co-authors are male, we consulted with female NGO workers to gain their perspectives of the exploitation of girls and women in the sex industry. We provide basic descriptive information for each of the 56 informants in Table 1. 


\section{Insert Table 1 about here}

Interviews. We interviewed different groups of individuals who could provide (potentially) contrasting viewpoints to answer our research question. These individuals included current (14) and former (9) workers forced into the sex industry, human traffickers and brothel managers (12), doctors (two), members of NGOs seeking to help sex workers (12), informants (six), and police officers assigned to the Kamathipura region (two). Our approach to informant triangulation ensured we could collect and validate responses from different groups of respondents. Also, before starting the interviews, we explained to respondents the study's purpose and promised anonymity. We also promised them that the names, places, and other references they mentioned during the interviews would not be published. We recorded and transcribed each of these interviews, resulting in 48 hours of interview audio and 539 pages of single-spaced text. These interviews served as our primary data source. We briefly describe the structure of these interviews and the information we sought to obtain.

Sex workers (23 people). The interviews with the sex workers included eight primary topics. (1) We started by asking questions about demographics, such as their age, birthplace, and family and economic conditions while growing up. (2) We then asked questions about why and how they entered this profession (i.e., prostitution, brothels, prostitution management, etc.), including who was involved in the recruitment process and who drove them to enter the profession. (3) If an individual indicated that it was not her choice to enter the profession, we asked more questions about how it happened, who was involved, what was done to her, and how she felt. (4) We then asked the sex workers about the initial conditions of entering the profession and delved deeper when they began to speak of others' actions toward them. (5) We also asked them about the economics of their profession, including how much customers paid, how much 
they received, and how much others received. Our objective here was to identify (as much as possible) where the money went once a payment was made. (6) Next, we asked them about their current living and working conditions, trying to gain insights into their social circumstances (i.e., presence of family, friends, and acquaintances) and how they were treated by their bosses, the other girls and women in the business, and customers. (7) To gain insights into their well-being, we asked them to describe their current situation, including asking them if they were happy. (8a) Finally, for current sex workers, we asked whether they had ever thought about leaving this work. We delved deeper into why they wanted to leave the work, what attempts (if any) they had made to leave, and the consequences of those attempts. We also asked if they would try to escape today. (8b) For former workers, we asked how they were able to leave the sex industry and asked about their life now.

Human traffickers and brothel managers. The interviews with the traffickers and brothel managers followed a four-topic semi-structured interview guide. (1) We asked them about themselves and their background. (2) We asked them to describe the nature of their job. We asked follow-up questions to probe their job responsibilities, activities, and earnings. (3) We then asked them questions about how and why their employees came to this area to work in prostitution. Again, we requested more information when they described how the girls and women were recruited and why they stayed in prostitution. (4) Finally, we asked about the economics of the business model, including who did what and how much they earned.

Doctors and NGO representatives seeking to help sex workers. The interviews with the doctors focused on two primary topics. (1) We asked about their current role working with those engaged in prostitution and how long they had been doing this work. (2) Then, we asked about the health of those working in prostitution, including prevention efforts and the level of medical 
care. In particular, we asked about the prevalence of HIV among current workers as well as other prominent health challenges (mental, physical, etc.) often experienced by those engaged in sex work.

For the representatives from NGOs — namely, Aadhar Trust (two representatives), Sai (five representatives), Udaan (two representatives), and Freeset (three representatives)—we interviewed founders, operational and senior staff members, and rehabilitation coaches. These individuals had considerable experience (more than ten years) rehabilitating girls and women from the sex industry. These interviews focused on four primary topics. (1) We asked about the role of each NGO vis-a-vis prostitution in the area, the NGO's degree of success in performing that role, and how long the individual had been working with this NGO or other NGOs (if applicable). (2) We then asked about their perspective on how girls and women enter prostitution. We delved deeper when these individuals spoke of trafficking and the practices of coercion. In particular, we were interested in the individuals involved, the tactics used by those coercing recruits, and the impact coercive practices had on the sex workers. (3) We also asked about the girls' and women's life in prostitution, why more do not leave, and why (and how) some are able to leave. We delved deeper into the nature of the obstacles blocking escape and how some are able to overcome these obstacles. (4) Finally, we asked them what the future holds in terms of human trafficking, the sex industry, and the life of those who work (or worked) in prostitution.

Police officers assigned to the Kamathipura region. The interviews with two local police officers focused on three main topics. (1) We asked about the nature of their job related to working in a region known for prostitution. We asked questions to gain insights into how covert the sex industry is and what the police think about both the industry and the women who work in 
it. (2) We then asked them about the extent of human trafficking, how the human trafficking process worked, and the success of law enforcement in curtailing it. (3) Finally, we asked whether workers try to escape this line of work, what the police do to help, and what these women can do after leaving.

Field notes and archival materials. We also captured field notes and research memos to document our observations about the interviews, the surrounding environment, and other reactions. We followed a 24-hour policy such that we completed the field notes within 24 hours of each interview and observation. Also, we collected secondary data from government reports, NGO reports, websites, newspaper articles, and academic articles. We primarily used these data to triangulate our findings and build a more extensive understanding of the empirical phenomenon of interest (Charmaz, 2014). We were mindful of using this information only as supplementary material to support our primary data because there have been questions about the veracity of such materials in terms of exaggerated claims (Weitzer, 2015) and even fabricated stories offered by NGOs to raise funding (field notes). Throughout our study, we repeatedly returned to our research memos and field notes, in which we recorded evolving impressions; iterative versions of emerging models; and summaries of what we heard, saw, and experienced while conducting interviews and field visits (Birks et al., 2008).

\section{Data Analysis}

Our analysis followed general tenets of inductive qualitative data analysis (Locke, 2001) and, more specifically, the two phases outlined by Pratt and Rosa (2003): (1) discovering and narrowing and (2) enriching and validating. In Phase 1, we began with a process of discovering and narrowing: analyzing our data by constructing categories of thoughts, feelings, and actions; exploring how these categories relate to each other; and highlighting unresolved issues. In Phase 
2, we began enriching and validating the data collected and analyzed in Phase 1 by verifying statements, synthesizing diverse concepts, adding to the categories of practices, exploring the mechanisms underlying the relationships between categories, and continuing reviews of relevant theories to sharpen insights. Thus, we constructed theory in two phases in which we identified the key surprising empirical phenomena, compared the data with extant literature, and developed an emerging categorization scheme from which we could theorize. Although we describe this process linearly in the sections that follow, it was more iterative in practice. The interactions were primarily driven by the differences in perspectives and interpretive lenses brought to the analysis from the authorship team's insider and outsider roles (see Bartunek \& Louis, 1996).

Phase 1. We began by (1) coding the data into categories of common meaning (see Locke, 2001). For example, we recognized multiple instances of how a husband, family member, or confidante lured a woman into prostitution and thus created a category labeled "recruitment through deception." After initially naming a category, we then (2) assigned new instances to it, or if an instance did not fit, we created a new category to capture this instance and other similarmeaning instances. As we re-coded the data, we adjusted the categories (e.g., changed a label to better capture the common meaning of the instances) and altered the assignment of instances to the emerging categories. As illustrated in Figure 1, the overarching categories include recruitment through deception, deconstruction to break their will, and limited reconstruction. We then (3) began exploring how the categories relate to each other. For example, each of the categories involves practices of heteronomy linked in the temporal order of deception, deconstruction, and limited reconstruction. Having established the categories and the basic relationships among those categories, we then (4) identified unresolved issues/conundrums in the literature. As we did this, we delved into the literature to unearth new insights. 
Phase 2. In Phase 2, we approached different data sources to triangulate the emerging categories of Phase 1 and tried to gain additional perspectives about human trafficking and exploitation in the sex industry. We focused our data collection and analysis on those who worked directly in the sex industry (e.g., brothel owners) as agents in transitioning girls and women to brothels and/or connecting customers to the women working in prostitution. We also followed up with additional NGOs to verify the categories that emerged from our analysis (from Phase 1). Therefore, the initial stages of Phase 2 enabled us to verify, add to, and enrich our emerging framework in preparation for developing a dynamic theoretical model. Furthermore, we time-bracketed our data to capture insights over time.

We began theorizing about the mechanisms linking the key concepts to understand the dynamic connections between the concepts. From these initial linkages, we developed a number of models, iterating back and forth between the structural concepts captured in our data, theory, and the (potential) dynamic relationships between concepts. This process resulted in the development of an emergent theoretical model. Having constructed an initial theoretical model, we then conducted final interviews with eight respondents in which we sought to (1) validate the emerging model and (2) identify gaps or misunderstandings in the model (Becker, 1970; Locke, 2001). That is, we progressively probed the nature of the relationships between the categories to try to understand the underlying mechanisms connecting the categories. From this information, we began to construct a revised model (Charmaz, 2006).

Insert Figure 1 about here

FINDINGS

The process begins with human traffickers targeting girls and women from impoverished environments to lure them into the sex industry. Vulnerable populations - those who are socially 
and economically marginalized (Schroeder \& Gefenas, 2009) are especially at risk of exploitation as individuals from these populations are likely to be eager to achieve the economic security promised by human exploiters. Our data suggest this is the case in the sex trafficking industry, where girls and women from impoverished rural backgrounds are targeted (field notes). They (and their family and community members) are desperate, making them prone to exploitation.

\section{Deceptive Recruiting of the Vulnerable}

The first key organizing process we observed involved deceptive recruiting: the structure and activities used to trick or lie to vulnerable individuals to funnel them into exploitive organizations. For example, one sex trafficker explained: "[We] tell the family that I am taking her [the female family member] for a year for a job opportunity. They pay six months upfront. Then, they pay the family [more money] later. [The payment goes] to their [the girls' and women's] parents" (Earaja ${ }^{2}$, Sex trafficking entrepreneur). Similarly, an NGO affiliate explained, To be born poor in our world is to be born vulnerable and in danger of exploitation. To be born female and poor is to greatly intensify the risks. If you are born a girl to parents of tea pickers in Assam in northeastern India (earning as little as $\$ 1.50$ a day), there is a good chance you will be sold to a local recruitment agent by your loved ones for around $\$ 50$, and the agent will sell you on to a city employer for up to $\$ 800$ and into a life of abuse and suffering.

We labeled this organizing "deceptive" to indicate how traffickers misled the targeted individuals (and their families) to start the recruitment process. For example, in the case Earaja mentioned above, payments did occur initially but were then stopped once the recruit had been "fully absorbed into the organization" (field notes). Similarly, we labeled this "recruiting" as the traffickers' explicit goal was to lure victims into a position in which their autonomy would systematically be curtailed for human exploitation. Our data reveal three key mechanisms that 
enabled the organizing of deceptive recruiting. We detail these mechanisms with representative quotations both in the section below and in Table 2.

\section{Insert Table 2 about here}

First, traffickers leveraged patriarchal cultural structures to coerce vulnerable individuals into the sex industry. Specifically, many of those in our data were forced into the sex industry by their husbands - these girls and women entered marriage (some as young as 11 years old, shortly after puberty) and found that their husbands' expectations of them were very different than their own. One NGO worker told us the following: "Yes. His wife is his means of earning [an income]. He is not earning himself. He is only using his wife. Whatever she earns, he takes it away from her because he does not want to work" (Udaan, NGO). This practice of using one's wife for income was reinforced due to the nature of these marriages as, more often than not, girls were married to significantly older men, resulting in a relationship founded on considerable power difference-older men wedding and domineering their child-aged brides. As an illustration, we noted the following in our field notes: "Sahasra was married when she was around 11 years old. [Her] husband was born and brought up in Mumbai, and she had kids from him. After a few years, her elder sister-in-law sold her for 85,000 rupees to a brothel in Mumbai with the husband's consent." Given the prevalence of marriage (in its various forms) as a fundamental (and foundational) institution from which other socio-cultural relationships emanate (Manning et al., 2007), traffickers appear to leverage inequality in these relationships to extract organizational value. We found that this suffocation (Finkel et al., 2014) and exploitation of girls (field notes) were behaviors that often involved family members.

Second, beyond the patriarchal control of husbands in marriage relationships over their young spouses, other male family members - usually a father, brother, uncle, and so forth- 
sometimes chose unmarried girls to be provided to a middleman for a single sum or ongoing payments. Publicly, these actions were explained as giving the girls a chance to earn an income with some attempt to paper over the reality that the young girls were being drawn into the sex industry with the ruse that they were being recruited into housework or some other form of respectable work. Furthermore, when we asked family members how much they knew about where the young family members were going, they suggested that they felt assured the girls would be given "work ... such as housekeeping work" (field notes). However, several NGO workers told us that families' deniability is not plausible. For example, a founder of Freeset (NGO) explained,

There's a whole lot of different ways that women get into prostitution. Generally, the root and the foundation of it is it begins with poverty and vulnerability. And then there are people that exploit them. I thought at the beginning, it was people stealing little girls on their way home from school, something like that. Although it does go on, the reality is, particularly in this part of the world, you know, the traffickers are neighbors and friends and mothers and fathers and aunties and uncles. For generation upon generation, a daughter is placed or put into prostitution so the money can go back to the village, so the family survives. There is a little shame [felt by the family] attached to that [selling a female family member]. Nobody talks about it, that it's been going on for generations. If you go to the village and say, "Does trafficking happen here," they say, "It doesn't happen here; it happens in the next village." So, you go to the other village, and they say, "It doesn't happen here; it happens in the village that you just came from." So, they're all ashamed. But the traffickers are known and often very, very close to most of the women [who are sold]. And so generally, that's the case. It's pretty difficult to understand why a father or mother would be involved in literally selling their own daughter. I was with a woman today, just a few hours ago, that actually did that - she put her own daughter in prostitution because they had bills to pay, medical bills for her husband. And so, the daughter was sacrificed. . . It actually becomes the norm - it becomes what you do, the way you think, the way you understand. And women go into prostitution, knowing they have a responsibility to support the family. Sometimes they are not welcome back home; their money is welcome, but they are not.

Finally, beyond the threat from family members, non-family members often used a recruiting practice we came to call "bait and switch," whereby they deceptively recruited girls and women for human trafficking and subsequent exploitation in the sex industry. There were 
two primary forms of bait - the promise of a good job and love. For example, some agents offered girls and women the promise of good work - usually housekeeping - to lure them to the city and later revealed that the women and girls would work in the sex industry. These agents were not necessarily men or strangers. For example, Saaiqa (Newly recruited sex worker) explained the deceptive practices used in her recruitment:

A lady brought me here when I was 10 . She had told me that she would give me housework and food and shelter and 5,000 rupees/month, and she said, you can send it to your mother. She told me this and brought me here. No one [in the family] knew about it. I had sneaked out with her and hidden it from them [the family]. . . . If I had told [the family], they wouldn't have allowed me to come.

For the bait of love, boys would court (but more like groom) girls so they would fall in love with them and want to marry. However, these boys then sold the girls to agents or directly to brothels. For example, Saketha (Experienced sex worker) talked of her boyfriend's deception:

When I was in the ninth grade, I fell in love with my cousin Ramesh. When I graduated [from the ninth grade], my parents started to get marriage proposals coming in, and they wanted to send me to someone else. Before that could happen, I told Ramesh, and we ran off to Bangalore. Ramesh sent me with his friend because he was scared of being caught with me. His friend took me to his auntie's house because Ramesh said he could not find any hotel rooms. He said I could sleep there, and they would come back for me in the morning. I slept there, and in the morning, the auntie woke me up and gave me tea to drink. About 10 or 15 minutes after drinking the tea, I do not remember anything. Two days later, I woke up in a taxi in Bombay. They took me to the red-light area. By this time, I was no longer drugged. I noticed that my dress had been changed. . . . I started screaming. I got scared all of a sudden. I started screaming and asking for Ramesh.

This organizing of deception is consistent with that reported in the literature on human trafficking (e.g., Reid, 2016). We highlight them here for several reasons. First, we found that these deceptive recruiting practices are only the start of a larger process of organizing for exploitation by breaking down victims' free will - it is the start of the journey of human exploitation, not the destination. Second, given the difficulty of gaining information on this illegal behavior and some legitimate concerns over the reporting of recruitment stories that turn 
out to be false or dubious to raise money from donors (Weitner, 2014; Zhang, 2009), we felt it was important to establish the recruitment practices ourselves. Therefore, we replicate the findings from some studies and validate anecdotal stories. Finally, the way the girls and women are recruited reflects the initial step in organizing human exploitation and provides a context in which the subsequent steps in the process are successful-success for the exploiters but obviously a highly adverse outcome for the victims.

\section{Entrapping through Isolation}

The second stage of our model involves organizing through what we called "entrapping through isolation," which entailed practices to keep (i.e., forcibly retain) girls and women in exploitive organizations. We found that organizing efforts to exploit workers systemically focused on "breaking [workers'] will" to obtain submission and obedience, eventually leading the victims to "give up hope of an escape" and even embrace their new role as sex workers (field notes). We illustrate the mechanisms of organizing the exploitation of vulnerable individuals' labor and provide illustrative quotes both in the manuscript and in Table 3.

First, brothel managers organized physical domination to break down girls' and women's willpower - or the "belief that people can control themselves [and their outcomes]," which has been described as "the greatest of human strengths" (Baumeister \& Tierney, 2012: 8). While willpower is essential for perseverance in the face of adversity (Baumeister \& Vohs, 2003), it can be depleted when it is continuously drawn upon to maintain high performance over time (Linder et al., 2014) or to deal with disruptive environmental features (Vohs, 2013), such as extreme poverty. This depletion of willpower may explain self-defeating or irrational choices by those suffering adversity to resist disruptive forces (Baumeister, Tice, \& Vohs, 2018). Our data reveal that organizing exploitation involved systematically depleting recruits' willpower through 
physical domination, including torture, rape, and threats of harm to family members, to entrap girls and women into the sex trade (field notes). For example, Sudakshima (Ex-sex worker) explained how she suffered physically:

They used to hit us with a belt, not give us food, give us shocks, and lock us in our rooms. We had to do it [prostitution] because we had to live and survive. When customers used to come to sleep with us, we used to hit them [to try and keep them off us], but they were drunk, so they would force themselves upon us [at the behest of the brothel owner].

Exploiters used physical violence and domination to convince girls and women that they had no alternatives but to serve their oppressors, perpetuating the belief that after entering into the sex trade, there were no other options beyond being subservient to their masters.

Second, beyond physical domination, exploiters organized psychological techniques to deplete recruits' willpower, including social isolation and disconnecting victims from reality. Social isolation involved (among other tactics) keeping girls and women alone in a room for extended periods (field notes). For example, one individual explained that after her initial subjugation, she and other recruits "were always inside for two years. I didn't get to go outside" (Seem, Experienced sex worker). Similarly, one NGO employee explained,

Initially, they [girls and women brought to the brothels] don't like it, and they try to run. But here there are madams and their gang of people with whom it is difficult to deal. [The sex workers] have to surrender. Plus, their home situation is not that great, so even if they go, what will they do there? The new recruits often try to escape for about one year. But [the brothel workers] are constantly watching, isolating, and guarding these girls. They don't let them go outside or let us [NGO workers] meet with them. (Aadhar Trust, NGO) As illustrated in the above quotes, social isolation involved restricting girls' and women's independent movement to a very narrow geographic space, such as limiting movement outside their building (i.e., the brothel), only allowing them to go to certain locations, and accompanying them anytime they left the building (e.g., Ekaja and Sruthi, Ex-sex-workers). Also, exploiters made efforts to cut ties between workers and family members or other potential allies from a worker's past. Brothel managers accomplished this by threatening to tell family members about a 
worker's involvement in the sex industry, which, if this came to be, would result in the family and village members disowning the worker (field notes). This act further highlights the proliferation of deceit and lies stemming from recruitment to entrapment: recruits are made to feel guilt and self-loathing for the very activities that were forced on them in many cases at the behest of family members who then disown them for engaging in the activities they sold them into. For example, Sria (Ex-sex worker) explained the power of this threat to tell her family:

They [brothel workers] all said no one will take you back. Your life will be a mess [if you leave the brothel]. They said they will tell everyone in my village what I am like [working in prostitution]. They will tell everyone, and your parents' reputation would be spoiled. Initially, they used to make me sleep next to my partner, and there was a small camera. So, they took a photo and said they will show everyone. I don't know whether they showed or not. I started crying so much.... I even tried to commit suicide. See here [she points to a scar]. They saved me. I got stitches. I understood nothing can be done and I have no support. Then two or three girls tried to make me understand: "We are also from good families, but our luck was also bad, and if we go [from the brothel], who will support us? And if we go, our family reputation would be spoiled, and our brothers and sisters will also be seen in that manner." According to me, I have already died.

Social isolation was coupled with efforts to disconnect recruits from reality, which involved instituting an alternative reality to which they felt bound. Specifically, this process involved using false narratives (as highlighted above) combined with alcohol and other drugs to make the girls and women feel numb and engage in activities they would not do if not in a druginduced state. For example, Sudakshima (Ex-sex worker) explained this practice:

They used to give us drugs, and they used to inject us as well so that we are numb and they [could] make us have sex. They used to give us injections. For six months, we tried a lot [to escape], but we couldn't leave the place [the brothel].

Similarly, another informant reported, "If we said no [to having sex with customers], they used to mix Coca-Cola with alcohol and give it to us. I remember everything, and we could not tell anyone about what was going on.... There was no use in telling people anyway" given the shame and lack of support (Sadhita, Ex-sex worker). In sum, recruits were constantly told stories 
like "You cannot go back [to your village] alive; you will be killed" (Saketha, Ex-sex worker), which, combined with a steady dose of mind-altering drugs and physical isolation, resulted in a fundamental disconnect from reality. Once separated from reality, it became easier to contain recruits as they submitted to their exploiters' new reality narratives (field notes).

Finally, exploiters organized contamination (Hodson \& Costello, 2007), convincing workers that they were now sullied and unfit (i.e., contaminated) for traditional society and could not return to the prior status quo nor advance to re-join society given their association with unsavory or disgusting behaviors and attributes (Olatunji et al., 2007). In general, organizing contamination worked due to the stigmatization of sex work in society despite clear incongruities between what people were willing to do (e.g., sell family members into the industry) and what they were willing to accept (e.g., caring for family members who had become stuck in the industry). For example, one former sex worker explained, "She [a brothel madam] said that if you attempt to leave here and if some customers recognize you, then you have to come back here; you will not be respected in society. . . . You can't settle in Mumbai. I will spread rumors about you" (Ekaja, Ex-sex worker). While manipulative, the madam's statement was not far from the truth about the recruit's now-contaminated reputation. Indeed, our data reveal how regardless of how girls and women are recruited (even if sold by their families), their families, villages, and society blame and stigmatize them for working in the sex industry (field notes). Brothel managers used society's stigma of girls and women who work in the sex industry to terminate victims' social networks and keep them in the sex industry — a spiral — as explained by a worker in a local NGO:

Once the girl gets exposure in this [works in prostitution], then she has to accept this profession as the family also does not accept them [people working in the sex industry]. . . . Any girl's family will not accept her because everyone knows. So, they feel 
that now, they don't have any other place to go, and they have to accept it [prostitution work]. They have to. (Aadhar Trust, NGO)

In sum, after successfully deceiving recruits, exploiters organized to break their victim's will to take away their feelings of autonomy and ensure they felt trapped in their current situation. Thus, entrapment practices functioned as a critical transitional process in converting unwilling recruits into organizational members that could be controlled, perpetuating the deepening process of exploitive organizing.

Insert Table 3 about here

\section{Extinguishing Alternatives by Building Barriers}

Having recruited and then entrapped victims into the sex industry successfully, exploiters then sought to deepen their workers' commitment to the cause by organizing barriers to extinguish any hopes of alternative life options. Indeed, as we indicated in our field notes, victory was accomplished for exploiters when the exploited (i.e., the recruited girls and women) effectively gave up and succumbed fully to the exploiters' wishes. This finding is consistent with scholarship on learned helplessness (Maier \& Selgiman, 1976), in which victims come to accept adverse environmental features they determine to be beyond their control - that is, they are helpless in the face of their tormentors (Peterson \& Seligman, 1983). Our data reveal two primary mechanisms that extinguish imagined alternatives to sex workers' reality. We present additional representative data in Table 4.

First, exploiters employed a financial contract with workers that created conditions for near-permanent indebtedness, providing a significant economic barrier that tethered workers' to the business long term through financial obligation. While exploiters promised workers their freedom if they paid off their debt, we found that this was nearly impossible for workers to 
accomplish (field notes). One NGO member explained that the amount a girl was purchased for represents her debt and that "debt is on the girl." These girls were also in debt to landlords, so "it was difficult for them to get out of it [debt]; they were in debt all the time." Sruthi (Sex worker) explained that she wants "to go home. I want to be good at home with my family. Because of my loan, that is why I can't go. I have a lot of loans to pay off. When I have paid it off, I will go home. I hope!" The result of this financial arrangement was that workers began the trade with significant financial obligations. Similarly, beyond servicing their initial debt, brothel managers provided workers loans for everyday necessities (which workers could not afford) with very high interest rates. Taken together, exploiters determined how much workers received from customers and thus how much went to debt payments. A worker at the Sia NGO explained this indebtedness well:

If you [the female sold to a brothel] settles into that brothel, then they [the brothel owners] give them [the girls and women working as prostitutes] loans. They come to know that the girl is settled, now she will not go anywhere, and she is the one who earns more. So, the brothel owner gives her 10,000 or 15,000 rupees. . . They [the brothel owners] charge interest. In the red-light area, there are also many madrasi [money lenders] around. They give loans with 10\%-20\% interest, and they come to collect the money daily — it has daily interest. The girls who are in need take a loan and repay it.

Second, exploiters organized to limit the network scope of their workers to those in the sex industry, including other girls and women working in prostitution, customers, and brothel managers. This tactic gave workers the impression that they were developing healthy relationships, but in reality, they were slipping deeper and deeper into their exploiters' circle of influence (field notes). For example, one former sex worker (Sudakshima) explained,

We stayed there [in a brothel] for almost two to two-and-a-half years. Then, we went out only when we were told to do a job. At that time, it was called lady piaros. We used to go to big hotels [where we met people in the industry]. We would get good food and clothes to wear. We interacted with and slept with politicians. They gave us 20,000 to 30,000 rupees. But we only got 1,000 rupees, and our mama [madam] took 9,000 rupees. This [type of socialization outside the brothel] went on for seven years. 
These outings gave workers a sense of agency and contact building as these experiences were substantially better than brothel work. However, the reality was they were stuck. Others explained a nervousness to meet people other than those in the exploitive organizations, which, while bad organizations, were at least known entities. One interviewee reported, "Since I reached Mumbai, I didn’t know where to go. I was afraid that someone would fool me again [similar to how she was deceived into entering this industry], so I stayed back here [in the brothel]" (Seem, Experienced sex worker).

Because of how the female sex workers were recruited (i.e., deceptively, from an impoverished context) and retained (through entrapment and indebtedness), these women and girls found it difficult to trust people. Even when they did trust people, these people were often not trustworthy because they were involved in the sex industry. Saarya (Experienced sex worker) told us how she came to trust a customer but was let down in the end: "There was a person who told me he would take me away from here forever. I trusted him and gave him my earnings of one-and-a-half years, and he ran away." Exploiters also used recruited girls' and women's reluctance to trust people as a basis for constructing stories about the dangers of interacting with strangers, particularly authorities. For example, Saketha (sex worker) explained how she was told she could not trust the police:

[The police] went to the house where they knew I was staying and rescued 12 girls from there. But when they came to my house, my keepers [brothel madam and workers] hid me in a water tank. There were five of us hiding in it, and it was full of water. And they slightly covered the top, and they told us that if the police caught us, we would have to save ourselves because the police would rape us and beat us and then publish our photo in the paper, and then everyone would know about us. That is why we stayed quiet in the water tank when the police came.

Indeed, it appears that such instances of police betraying girls and women working in the sex industry are commonplace. Sriya (Newly recruited sex worker) told us that she "went to the 
police to register a complaint. They put me in jail for three months. My brothel paid 60,000 rupees in bail money to secure my release." Therefore, workers found it difficult to trust other people; they had little faith in people's goodness, resulting from the way their exploiters organized the process - namely, recruited, managed, and exploited. However, exploiters were able to use girls' and women's distrust of some to form distrust of all outsiders, which included those who could either help them escape the sex industry or help them after they eventually left the sex industry. For example, one member of an NGO told us the following:

Some people must have betrayed them [the girls and women working in prostitution].... [They] do not trust people easily. They used to say to us [NGO workers] that there are many people like you that come to us and then betray us. So, they do not trust us. So, we have to convince them that we are from an NGO and this is for your betterment-your future will improve. In the future, we can help you if you have any issues. We are here to help you. After that, they started trusting us. (Sai, NGO)

The seeming impossibility of leaving the sex industry compounded by resource obligations (e.g., indebtedness) and limited social capital meant that these girls and women could be exploited in the sex industry in perpetuity (i.e., they lacked agency to leave). With their hope of escape to a different life extinguished, exploiters gave them some small rewards in terms of greater freedoms, although still within the broader constraints established for their effective exploitation in the sex industry. For example, Spruce (2017: 1) noted that girls and women working in prostitution over an extended period find that "their madams or traffickers will increasingly offer more freedom, while the threat of abuse lingers over them causing an abusive relationship to develop between abuser and victim (think Stockholm Syndrome).” Therefore, organizing to exploit the labor of these vulnerable individuals involved practices to (1) bring workers closer to the illegal business, (2) give them some autonomy, and (3) create some (dark) form of belonging that leads to them becoming exploiters themselves. 


\section{Insert Table 4 about here}

\section{Converting the Exploited to Exploiters}

We found that exploiters who relied on organizing to eliminate workers' agency engaged in different tactics to retain and convert employees into seemingly willing advocates for the organizations they initially detested. Specifically, having isolated and then defeated the free will of sex-worker recruits, exploiters then sought to deploy these workers as advocates for the trade, thus perpetuating the cycle of human exploitation. Although a small minority of workers did escape and seek the help of NGOs (as illustrated in Figure 2), the majority took on new management roles in the sex industry once their "usefulness as sex workers" had expired (field notes). These new roles included recruiters, brothel madams, and enforcers of isolation and barrier policy enforcement. This approach to converting the exploited to exploiters appears to serve two major purposes: it creates a path for socially outcasted workers who are physically damaged from years of enduring this risky, dangerous career, which usually becomes apparent by the time they have reached the age of 30 (according to Sadhita and Sagarika, both ex-sex workers), and provides organizational staffing for recruiting and exploiting new workers (field notes). Our data reveal two primary organizing mechanisms that facilitated the conversion of the exploited to exploiters.

First, former sex workers were groomed into leadership roles in the pattern of a leadership-development program, including becoming brothel managers and even managers of their own exploitive ventures. Indeed, some exploited women became the most successful exploiters - they selected vulnerable girls and women, engaged in deceptive recruiting practices to lure them into the sex industry, engaged in practices to break their will to ensure they felt trapped, and/or engaged in other practices so that these girls and women were exploited for an 
extended period. Specifically, exploiters organized these women into new roles given their understanding of the industry and how to engage customers and their knowledge of what would help maintain the cycle of exploiting the vulnerable. For example, we documented the following account in our field notes about Eilin, who was exploited and now is an exploiter:

Eilin worked in prostitution for a while, and then after understanding how the entire process works, she got into supplying girls to customers. Eilin terms this as her business as it's her source of income. She says that although she is not happy with the kind of work that she is doing, she does it because her survival is at stake. . . Eilin feels that working in the sex industry is definitely a social stigma but states that she doesn't care about it; when she wanted help from people, no one came up and extended help to her. She states that today she is quite happy and satisfied.

Second, former sex workers were groomed to recruit new girls and women for existing human traffickers and brothels. The organizing that was used to select, recruit, trap, and exploit these women meant that they were (1) ideal candidates for the recruiter role and (2) had few career choices remaining other than working in the sex industry. Even more, enduring a lifetime of exploitation altered these workers' mindset — their way of thinking and seeing the world. At a minimum, continuous exposure to the adverse conditions of working in the sex industry over an extended period desensitized these women to the industry's destructive practices and normalized the day-to-day life and operations within the sex industry. This normalization of their life as a victim resulted in the normalization of becoming a victimizer. For example, Sudakshima (Ex-sex worker) told us the following:

I started enjoying this life because I was getting money and was getting to go to new places. And I had no option that someone from my home is alive so I go there. I had no sisters and grandparents. [As a recruiter and worker] I started enjoying that life, having cigarettes, drinking, roaming around. There was a time that I did not like that place [the brothel], but later I liked it. For example, if we get a pet dog, first we are scared of it, but later we get used to it. So, I got use to this life.

While it is potentially shocking that victims of trafficking could become involved in the trafficking trade, other research on child sexual abuse has shown that in some situations, the 
abused can become abusers (Plummer \& Cossins, 2016). We found that the outcome of the exploited becoming exploiters is consistent with the notion of a cycle of human exploitationthe ongoing enactment of this cycle involved at least three mechanisms.

First, sex workers turned exploiters developed non-transferrable competencies due to their years in the sex industry. Indeed, after starting to earn money from the sex industry after a considerable period (e.g., debt paid off), workers still required an income to feed, house, and educate their children and also to send money back to their families in their villages (even those families that sold them into the sex industry in the first place). Therefore, having established competence over many years, they chose to earn money that they could not otherwise acquire through other careers. For this reason, despite the horror of the profession, they knew they could make do by doing what they knew: engaging in the practices of selecting, recruiting, trapping, and exploiting girls and women.

Second, as part of their recruitment and ongoing exploitation, these women lost trust in others (because others had deceived them) and had all ties outside the sex industry cut (which are unlikely to be re-established because of society's stigmatization of those who work in the sex industry). Therefore, despite the seeming incongruity, these sex workers found a sense of belonging with those associated with the sex industry, including other women who work in prostitution and brothel owners. This sense of belonging meant that their social capital and shared sense of meaning were tied to this industry. For example, Ekaa (Sex trafficker) explained how she transitioned from directly working in prostitution to becoming an agent of prostitution:

There was a stage where there was nothing at home - nothing to eat, no education for the children. Then I again had to go into that line [the sex industry] after looking at my condition. I contacted the agent again since she was my good friend. She said, 'Don't go back in that line since you never liked it. Instead, do this [work as an agent of prostitution]. I stayed next to the agent's house, took a room there, and learned from her how to do things. Then I started on my own [as an agent]. I had my zone; she had her 
zone. . . . If I ask for 6,000 rupees from them [the customers], then I give them [the women engaged in prostitution] 3,000 and keep 3,000 rupees for myself. . . I have 10 rooms that I rent for about 30,000 to 40,000 rupees a month. . . The one bad thing in this line [prostitution] is that the people who like you in the night are the same people who give you a bad word in the morning. Society throws us to one side, but we are human beings.

Finally, having been stripped of all autonomy for years, these former sex workers were allowed to regain some autonomy by making decisions that influenced the business and others' lives. For example, Eilin explained the benefits of autonomy and money from being an agent in the sex industry:

I used my brain, and I was already staying in Mumbai, and I knew how people work here. So, then I started directly picking up [customers], and I started to recognize people, and I then started supplying [girls for prostitution]. Currently, this is a business for me. I am getting good money. ... . No [I do not feel helpless now]. I am used to it. I used to feel [helpless] in the beginning, but now I don't feel any such thing.

\section{DISCUSSION}

In Figure 2, we display our grounded theoretical model of organizing the exploitation of vulnerable individuals for labor. Our primary contribution to the management literature is offering this model and detailing how this associated organizing to control others can create a cycle of human exploitation. We view organizing the exploitation of the vulnerable as a fourphase cycle of human exploitation. Human exploitation is not just about individual and community poverty and vulnerability; not just about deceptive recruiting practices; not just about physical, social, and psychological mechanisms of domination and entrapment; and not just about eliminating alternative career and life options. Rather, organizing for exploiting the vulnerable for their labor involves all of these activities. Indeed, these activities are complementary and self-reinforcing to extinguish workers' agency for ongoing human exploitation. Therefore, organizing for exploitation involves the orchestration of exploitive structures, processes, and organizational configurations (Sirmon et al., 2007), whereby the 
exploiter generates a systematic assault on workers' autonomy and agency. This assault on workers' agency is not necessarily the flipside of providing autonomy, so the current study offers a counterweight to extant management studies (e.g., Liu et al., 2011; Sheldon \& Elliot 1998; Thompson \& Prottas, 2006) and the costs to organizations that constrain workers' autonomy (Oldham \& Hackman, 1981; Slade Shantz et al., 2020). Indeed, previous studies focusing on enabling autonomy in the workforce have highlighted a win-win — both the organization and the workers benefit from greater worker autonomy. However, we offer a different perspective-a win-lose situation in which the organization benefits (in terms of profitability) from harming the workers (reducing worker agency). Future research will hopefully explore how individuals and organizations can obstruct the process of organizing the exploitation of human labor and perhaps reverse its effects to rehabilitate victims.

Insert Figure 2 about here

Furthermore, management research has explored the issue of human exploitation mostly from the perspective of how organizations can detect others within their supply chains engaging in human exploitation (Crane et al., 2019; Kim et al., 2019; LeBaron, 2020; LeBaron \& Lister, 2015; LeBaron et al., 2017). This research is important because if the demand for goods produced by exploited labor is reduced, the practice may be attenuated or eliminated. Therefore, it is also important that management scholars move closer to the source of human exploitation to understand how it is initiated, sustained, and perpetuated. This study investigated the actors who have exploited vulnerable individuals and the lived experiences of those who have been exploited. Therefore, we complement previous management research from the buyers' perspective on how to constrain their suppliers' choices away from human exploitation (Kolk \& 
van Tulder, 2002; Plambeck \& Taylor, 2016) by offering the suppliers' (or producers') organizing mechanisms for containing (and eliminating) the choices of their suppliers (vulnerable individuals forced into labor). How can organizations directly intervene and prevent suppliers from exploiting labor or otherwise help suppliers find sources of advantage that do not require labor exploitation?

Another advantage for organizations comes from recruiting workers (Powell \& Baker, 2017; Wang \& Zatzick, 2019). Organizations with strong cultures often recruit individuals who are open to inculcation (Battilana \& Dorado, 2010) or those who fit the focal organization in terms of personality (Resick, Baltes \& Shantz, 2007), values (Cable \& Judge, 1996), and cognitive style (Brigham, DeCastro \& Shepherd, 2007). In exploitive organizing, recruitment involves using existing social relationships or creating new ones to deceptively recruit (i.e., trick) individuals to diminish and eliminate those individuals' agency and exploit their labor for an extended period. Therefore, rather than recruit the vulnerable to provide a sense of belonging (Olkkonen \& Lipponen, 2006), exploitive organizing involves using the vulnerabilities of those around targets to recruit them and destroy their sense of belonging. Therefore, while poverty may drive people to choose to engage in onerous work (Gans, 1972; Paharia et al., 2009), these exploited workers do not choose but are deceived and forced into such work. While management research has highlighted many attributes of effective recruiting (e.g., Ho \& Kuvaas, 2020; Singh \& Agrawal, 2011), it has devoted less attention to the role of deceptive recruiting. Here, we highlight how poverty and other vulnerabilities influence the selection and recruitment of workers for exploitation. Future research can explore the different modes of deceptive recruiting, why some deceptions are more successful than others, and who is most vulnerable to being deceptively recruited. 
Furthermore, effective organizing has been associated with workers experiencing freedom and independence (Amabile, 1988; Burgelman, 1983). However, organizing for the exploitation of vulnerable people involves entrapment; the mechanisms break down free will and disconnect individuals to sever ties from their previous life and obstruct their ability to create a positive future. While those outside their workgroups often stigmatize dirty workers, these workers can find positive meaning in their work and a sense of belonging with others engaged in the same work and therefore often choose to continue to perform this type of work (Ashforth \& Kreiner, 1999; Ashforth et al., 2007). The organizing of human exploitation uses the social stigma of certain types of work to entrap individuals with negative meanings attached and feelings of loneliness. Therefore, exploiters can use society's values to entrap individuals in dirty work. Also, exploiters erect barriers to exit. Indeed, the initial recruitment of workers for exploitation lays the foundation for ongoing exploitation. Specifically, workers can become indebted (forced to pay off the amount the exploiter bought them for and money borrowed to buy necessities), which creates a financial exit barrier. Furthermore, the deception involved in recruiting can shatter trust in others such that exploited workers are unable to build relationships that may help them escape. We hope that scholars explore how to change or blunt the role of stigma in entrapment, remove exit barriers for those whose labor is exploited, and rebuild trust (after it has been shattered) so victims can rejoin society.

Our findings and model also provide nuances to social cognitive theory (Benight et al., 2018; Bandura, 1989, 2001), which has largely focused on the benefits of gaining agency but has also explored the implications of events that take away agency. Specifically, scholars can explore how exploiters can take away an individual's agency by focusing on individuals with agency who face an initial environment in which they are vulnerable to exploitation and a constructed 
environment that entraps them. Such individuals are led to the behavior of working against their will and eventually exploiting other vulnerable people, creating a person-environment-behavior cycle of human exploitation. As we understand more about this cycle, we are in a better position to research how to disrupt the cycle and bring it to an end. We suspect that researchers will look to interventions of the person, environment, and behavior from a social cognitive perspective to counter the loss of agency and the resulting labor exploitation.

Finally, our insights about organizing the exploitation of vulnerable individuals contribute to knowledge of the perpetuation of human exploitation. For example, we contribute to the literature on human trafficking (e.g., accounts of recruiting individuals through trauma bonds [Dorais \& Corriveau, 2009; Reid \& Jones, 2011]) and modern slavery (e.g., accounts of debt bondage entrapping individuals in human exploitation [Bales, 2004; Friebel \& Guriev, 2006; LeBaron, 2014]) by offering a model of organizing human exploitation across its various phases based on the lived experiences of exploited individuals. We also complement these accounts in the human trafficking and modern slavery literature by explaining how this process perpetuates a cycle of exploiting vulnerable individuals. The mechanisms that perpetuate human exploitation involve both society's stigmatization of the work and the community's extreme poverty, as well as the organizing of a succession path in which the exploited become exploiters. This succession is an extreme form of grooming a worker to become a manager. Being groomed for management involves identifying leadership potential, giving greater responsibility for task performance, and monitoring task performance (Rothwell, 2010). Similarly, but from a low base of worker agency, succession to the position of exploiter involves providing a worker with small opportunities for agency and the development of industry relationships. As these workers gain agency and relationships, they can use them to take away others' agency to exploit their labor. 
Future research can explore how these women mentally reconcile exploiting girls and women in ways that they experienced themselves as traumatic.

\section{CONCLUSION}

In this paper, we theorized on an important yet largely overlooked process in management scholarship_organizing vulnerable individuals' exploitation for labor. We found that while economic poverty and other vulnerabilities contribute to workers choosing different forms of onerous work, some people are forced to work against their will. Organizing to eliminate workers' autonomy, just like other forms of organizing, provides a basis for capabilities, efficiencies, and scale to exploit an opportunity profitably. In sketching out the process of organizing human exploitation, we began to uncover the organizing tactics that support exploitive organizing to inform policy that might (1) facilitate the termination of such cycles, (2) assist victims of exploitive organizing in both avoiding and exiting these organizations, and (3) make it more difficult to recruit individuals to work against their will. We hope future research builds on the current study to investigate the organizing practices actors use to exploit human labor to generate solutions to this form of human suffering. 


\section{References}

Albanese, J. 2007. A criminal network approach to understanding and measuring trafficking in human beings. In E.U. Savona \& S. Stefanizzi (Eds.) Measuring human trafficking: 5571. Champaign, I1.: Springer.

Amabile, T. M. 1988. A model of creativity and innovation in organizations. Research in Organizational Behavior, 10(1): 123-167.

Ashforth, B.E., \& Kreiner G.E. 2014. Dirty work and dirtier work: Differences in countering physical, social, and moral stigma. Management and Organization Review, 10(1): 81108.

Aradau, C. 2004. Security and the democratic scene: Desecuritization and emancipation. Journal of International Relations and Development, 7(4): 388-413.

Ashforth, B.E., \& Kreiner G.E. 1999. How can you do it? Dirty work and the challenge of constructing a positive identity. Academy of Management Review, 24(3): 413-434.

Ashforth, B., Kreiner, G. Clark, M., \& Fugate, M. 2007. Normalizing dirty work: Managerial tactics for countering occupational taint. Academy of Management Journal, 50(1): 149174.

Baker, L.M., Dalla R.L., \& Williamson C. 2010. Exiting prostitution: An integrated model. Violence Against Women, 16(5): 579-600.

Bales, K. 2004. New slavery: A reference handbook. ABC-CLIO.

Bandura, A. 1989. Human agency in social cognitive theory. American Psychologist, 44(9): $1175-1184$.

Bandura, A. 2001. Social cognitive theory: An agentic perspective. Annual Review of Psychology, 52(1): 1-26.

Barron, I. M., \& Frost, C. 2018. Men, boys, and LGBTQ: Invisible victims of human trafficking. In L. Walker, G. Gaviria \& K. Gopal (Eds.) Handbook of sex trafficking: 73-84. Champaign, Il: Springer.

Bartunek, J. M., \& Louis, M. R. 1996. Insider/outsider team research. Thousand Oaks, CA: Sage Publications.

Batsyukova, S. 2007. Prostitution and human trafficking for sexual exploitation. Gender Issues, 24(2): 46-50.

Battilana, J., \& Dorado, S. 2010. Building sustainable hybrid organizations: The case of commercial microfinance organizations. Academy of Management Journal, 53(6): 14191440 .

Baumeister, R. F., Tice, D. M., \& Vohs, K. D. 2018. The strength model of self-regulation: Conclusions from the second decade of willpower research. Perspectives on Psychological Science, 13(2): 141-145.

Baumeister, R. F., \& Tierney, J. 2012. Willpower: Rediscovering the greatest human strength. New Yoprk, NY: Penguin Books.

Baumeister, R. F., \& Vohs, K. D. 2003. Self-regulation and the executive function of the self. Handbook of Self and Identity, 1: 197-217.

Becker, H. S. 1970. Sociological work: Method and Substance. Chicago, IL: Aldine.

Benight, C.C., Harwell A., \& Shoji K. 2018. Self-regulation shift theory: A dynamic personal agency approach to recovery capital and methodological suggestions. Frontiers in Psychology, 9: 1-8. 
Benoit, C., Jansson S.M., Smith M., \& Flagg J. 2018. Prostitution stigma and its effect on the working conditions, personal lives, and health of sex workers. Journal of Sex Research, 55(4-5): 457-471.

Birks, M., Chapman, Y., \& Francis, K. 2008. Memoing in qualitative research: Probing data and processes. Journal of Research in Nursing, 13(1): 68-75.

Brigham, K. H., De Castro, J. O., \& Shepherd, D. A. 2007. A person-organization fit model of owner-managers' cognitive style and organizational demands. Entrepreneurship Theory and Practice, 31(1): 29-51.

Brockner, J., \& Rubin, J. Z. 2012. Entrapment in escalating conflicts: A social psychological analysis. Champaign Il.: Springer.

Bryant A. 2002. Re-grounding grounded theory. Journal of Information Technology Theory and Application, 4: 25-42.

Burgelman, R. A. 1983. A process model of internal corporate venturing in the diversified major firm. Administrative Science Quarterly, 28: 223-244.

Cable, D. \& Judge, T. A. 1996. Person-organization fit, job choice decisions, and organizational entry. Organizational Behavior and Human Decision Processes, 67(3): 294-311.

Caruana, R., Crane, A., Gold, S., \& LeBaron, G. 2021. Modern slavery in business: the sad and sorry state of a non-field. Business \& Society, 60(2): 251-287.

Catron, P. 2019. The citizenship advantage: Immigrant socioeconomic attainment in the age of mass migration. American Journal of Sociology, 124(4): 999-1042.

Charmaz, K. 2014. Constructing grounded theory. London, U.K.: Sage.

Charmaz, K. 2006. Constructing grounded theory. London, U.K.: Sage.

Chen, L., \& Lee, H. L. 2017. Sourcing under supplier responsibility risk: The effects of certification, audit, and contingency payment. Management Science, 63(9): 2795-2812.

Chia, R. 1999. A 'rhizomic'model of organizational change and transformation: Perspective from a metaphysics of change. British Journal of Management, 10(3): 209-227.

Cieslak, R., Benight C., Schmidt N., Luszczynsk, A., Curtin E., Clark R.A., \& Kissinger P. 2009. Predicting posttraumatic growth among Hurricane Katrina survivors living with HIV: The role of self-efficacy, social support, and PTSD symptoms. Anxiety, Stress, and Coping, 22 (4): 449-463.

Clarke, A.E. 2005. Situational analysis: Grounded theory after the postmodern turn. Thousand Oaks, CA: Sage Publications.

Crane, A. 2013. Modern slavery as a management practice: Exploring the conditions and capabilities for human exploitation. Academy of Management Review, 38(1): 49-69.

Crane, A., LeBaron, G., Phung, K., Behbahani, L., \& Allain, J. 2021. Confronting the Business Models of Modern Slavery. Journal of Management Inquiry, 1056492621994904.

Crosina, E., \& Pratt, M. G. 2019. Toward a model of organizational mourning: The case of former Lehman Brothers bankers. Academy of Management Journal, 62(1): 66-98.

Deci, E.L., Olafsen A.H., \& Ryan R.M. 2017. Self-determination theory in work organizations: The state of a science. Annual Review of Organizational Psychology and Organizational Behavior, 4: 19-43.

Desyllas, M. C. 2007. A Critique of the Global Trafficking Discourse and US Policy. Journal of Sociology \& Social Welfare, 34(4): 57.

Di Tommaso, M.L., Shima I., Strøm S., \& Bettio F. 2009. As bad as it gets: Well-being deprivation of sexually exploited trafficked women. European Journal of Political Economy, 25(2): 143-162. 
Dorais, M., \& Corriveau P. 2009. Gangs and girls: Understanding juvenile prostitution. Montreal, Canada: McGill-Queen's Press.

Duncan, F. 1996. A glimpse of hell: Reports on torture worldwide. London, U.K.: Biddles.

Dunmore, E., Clark D.M., \& Ehlers A. 2001. A prospective investigation of the role of cognitive factors in persistent posttraumatic stress disorder (PTSD) after physical or sexual assault. Behaviour Research and Therapy, 39(9): 1063-1084.

Dutton, D.G., \& Painter S. 1993. Emotional attachments in abusive relationships: A test of traumatic bonding theory. Violence and Victims, 8(2): 105-120.

Dutton, J. E., Worline, M. C., Frost, P. J., \& Lilius, J. 2006. Explaining compassion organizing. Administrative Science Quarterly, 51(1): 59-96.

Enclow, A.J., \& Swisher, S.N. 1986. Interviewing and patientcare, 3rd ed. New York: Oxford University Press.

Ehlers, A., Maercker A., \& Boos A. 2000. Posttraumatic stress disorder following political imprisonment: The role of mental defeat, alienation, and perceived permanent change. Journal of Abnormal Psychology, 109(1): 45-55.

Eisenhardt, K. M. 1989. Making fast strategic decisions in high-velocity environments. Academy of Management Journal, 32(3): 543-576.

Eisenhardt, K. M., Graebner, M. E., \& Sonenshein, S. 2016. Grand challenges and inductive methods: Rigor without rigor mortis. Academy of Management Journal, 59(4): 11131123.

Farrell, A. 2009. State and local law enforcement responses to human trafficking: explaining why so few trafficking cases are identified in the United States. In W.F. McDonald (Ed.) Immigration, crime and justice: 243-259. Bingley, U.K.: Emerald Group Publishing.

Farley, M., \& Barkan H. 1998. Prostitution, violence, and posttraumatic stress disorder. Women and Health, 27(3): 37-49.

Farrell, A., McDevitt, J., \& Fahy, S. 2010. Where are all the victims? Understanding the determinants of official identification of human trafficking incidents. Criminology \& Public Policy, 9(2): 201-233.

Finkel, E. J., Hui, C. M., Carswell, K. L., Larson, G. M. 2014. The suffocation of marriage: Climbing Mount Maslow without enough oxygen. Psychological Inquiry, 25: 1-41.

Friebel, G., \& Guriev, S. 2006. Smuggling humans: a theory of debt-financed migration. Journal of the European Economic Association, 4(6): 1085-1111.

Gans, H. J. 1972. The positive functions of poverty. American Journal of Sociology, 78(2), 275289.

George, E., \& Stanley, M. 2019. Exploring the occupational injustices of human trafficking. Journal of Occupational Science, 26(3): 394-407.

Gephart, R. P., Jr., 2004. Qualitative research and the Academy of Management Journal. Academy of Management Journal, 47: 454-462.

Gezinski, L., \& Karandikar S. 2013. Exploring needs of sex workers from the Kamathipura redlight area of Mumbai, India. Journal of Social Service Research, 39: 552-561.

Gil, V.E., Wang M.S., Anderson A.F, Lin G.M., \& Wu Z.O. 1996. Prostitutes, prostitution and STD/HIV transmission in mainland China. Social Science and Medicine, 42(1): 141-152.

Gilbert, P., \& Allan S. 1998. The role of defeat and entrapment (arrested flight) in depression: an exploration of an evolutionary view. Psychological Medicine, 28(3): 585-598. 
Gilbert, P., \& Gilbert J. 2003. Entrapment and arrested fight and flight in depression: An exploration using focus groups. Psychology and Psychotherapy: Theory, Research and Practice, 76(2): 173-188.

Golden-Biddle, K., \& Locke, K. 2006. Composing qualitative research. Thousand Oaks, CA: Sage Publications.

Gordon, J. 2005. Suburban sweatshops. Cambridge MA: Harvard University Press.

Haack, P., Schoeneborn, D., \& Wickert, C. 2012. Talking the talk, moral entrapment, creeping commitment? Exploring narrative dynamics in corporate responsibility standardization. Organization Studies, 33(5-6): 815-845.

Hazeldine-Baker, C.E., Salkovskis P.M., Osborn M., \& Gauntlett-Gilbert J. 2018. Understanding the link between feelings of mental defeat, self-efficacy and the experience of chronic pain. British Journal of Pain, 12(2): 87-94.

Hebert, L. A. 2016. Always victimizers, never victims: Engaging men and boys in human trafficking scholarship. Journal of Human Trafficking, 2(4): 281-296.

Ho, H., \& Kuvaas, B. 2020. Human resource management systems, employee well-being, and firm performance from the mutual gains and critical perspectives: The well-being paradox. Human Resource Management, 59(3): 235-253.

Hodson, G., \& Costello, K. 2007. Interpersonal disgust, ideological orientations, and dehumanization as predictors of intergroup attitudes. Psychological Science, 18(8): 691698.

Hofmann, H., Busse, C., Bode, C., \& Henke, M. 2014. Sustainability-related supply chain risks: Conceptualization and management. Business Strategy and the Environment, 23(3): 160172.

Huda, S. 2006. Sex trafficking in south Asia. International Journal of Gynecology \& Obstetrics, 94(3): 374-381.

ILO, 2012. Hard to see, harder to count. Geneva: ILO.

ILO.org. Forced labor, modern slavery and human trafficking. https://www.ilo.org/global/topics/forced-labour/lang--en/index.htm

Jones, S. V. 2010. The invisible man: The conscious neglect of men and boys in the war on human trafficking. Utah Law Review, 1143.

Jones, L., Engstrom, D. W., Hilliard, T., \& Diaz, M. 2007. Globalization and human trafficking. Journal of Sociology \& Social Welfare, 34: 107.

Jordan, J., Patel, B., \& Rapp, L. 2013. Domestic minor sex trafficking: A social work perspective on misidentification, victims, buyers, traffickers, treatment, and reform of current practice. Journal of Human Behavior in the Social Environment, 23(3): 356-369.

Kenyon, S., \& Schanz, Y. 2014. Sex trafficking: Examining links to prostitution and the routine activity theory. International Journal of Criminology and Sociology, 3: 61-76.

Kim, S., Wagner, S. M., \& Colicchia, C. 2019. The impact of supplier sustainability risk on shareholder value. Journal of Supply Chain Management, 55(1): 71-87.

Kleim, B., Ehlers A., \& Glucksman E. 2012. Investigating cognitive pathways to psychopathology: Predicting depression and posttraumatic stress disorder from early responses after assault. Psychological Trauma: Theory, Research, Practice, and Policy, 4(5): 527-537.

Kolk, A., \& Van Tulder, R. 2002. Child labor and multinational conduct: a comparison of international business and stakeholder codes. Journal of Business Ethics, 36(3): 291-301. 
Konrad, R. A., Trapp, A. C., Palmbach, T. M., \& Blom, J. S. 2017. Overcoming human trafficking via operations research and analytics: Opportunities for methods, models, and applications. European Journal of Operational Research, 259(2): 733-745.

LeBaron, G. 2020. Combatting modern slavery: Why labour governance is failing and what we can do about it. Hoboken, N.J.: John Wiley \& Sons.

LeBaron, G. 2014. Reconceptualizing debt bondage: Debt as a class-based form of labor discipline. Critical Sociology, 40(5): 763-780.

LeBaron, G., \& Lister, J. 2015. Benchmarking global supply chains: the power of the 'ethical audit' regime. Review of International Studies, 41(5): 905-924.

LeBaron, G., Lister, J., \& Dauvergne, P. 2017. Governing global supply chain sustainability through the ethical audit regime. Globalizations, 14(6): 958-975.

Larson, R. B. 2018. Controlling social desirability bias. International Journal of Market Research, 61(5): 534-547.

Linder, J. A., Doctor, J. N., Friedberg, M. W., Nieva, H. R., Birks, C., Meeker, D., \& Fox, C. R. 2014. Time of day and the decision to prescribe antibiotics. JAMA Internal Medicine, 174(12): 2029-2031.

Liu, D., Chen X.P., \& Yao X. 2011. From autonomy to creativity: A multilevel investigation of the mediating role of harmonious passion. Journal of Applied Psychology, 96 (2): 294309.

Locke, K. 2001. Grounded theory in management research. London, U.K.: Sage Publications.

Maignan, I., Hillebrand, B., \& McAlister, D. 2002. Managing socially-responsible buying: how to integrate non-economic criteria into the purchasing process. European Management Journal, 20(6): 641-648.

Maier, S. F., \& Seligman, M. E. 1976. Learned helplessness: Theory and evidence. Journal of Experimental Psychology: General, 105(1): 3-46.

Maitlis, S. 2009. Who am I now? Sensemaking and identity in posttraumatic growth. In Exploring positive identities and organizations (pp. 71-100). Psychology Press.

Miller, J. R. 2008. Call it slavery. Wilson Quarterly, 32(3): 52-56.

Mirowsky, J. 1985. Depression and marital power: An equity model. American Journal of Sociology, 91(3): 557-592.

Mobasseri, S. 2019. Race, place, and crime: how violent crime events affect employment discrimination. American Journal of Sociology, 125(1), 63-104.

Murphy, J. H., Clifford, J. J., \& Vargas, C. 2019. Scaling Up Corporate Social Responsibility: Coffee Farming in Chiapas, Mexico. In R. Schmidpeter, N. Capaldi, S. Idowu \& H.A. Sturenberg (Eds.) International Dimensions of Sustainable Management: 231-248. Chapaign, Il:: Springer.

Núñez, G., \& Heyman, J. 2007. Entrapment processes and immigrant communities in a time of heightened border vigilance. Human Organization, 66(4): 354-365.

Olatunji, B. O., Lohr, J. M., Sawchuk, C. N., \& Tolin, D. F. 2007. Multimodal assessment of disgust in contamination-related obsessive-compulsive disorder. Behaviour Research and Therapy, 45(2): 263-276.

Oldham, G. R., \& Hackman, J. R. 1981. Relationships between organizational structure and employee reactions: Comparing alternative frameworks. Administrative Science Quarterly, 26(1): 66-83. 
Olkkonen, M. E., \& Lipponen, J. 2006. Relationships between organizational justice, identification with organization and work unit, and group-related outcomes. Organizational Behavior and Human Decision Processes, 100(2): 202-215.

Oram, S., Abas, M., Bick, D., Boyle, A., French, R., Jakobowitz, S., Khondoker, M., Stanley, N., Trevillion, K., Howard, K., \& Zimmerman, C. 2016. Human trafficking and health: a survey of male and female survivors in England. American Journal of Public Health, 106(6): 1073-1078.

Oram, S., Zimmerman, C., Adams, B., \& Busza, J. 2011. International law, national policymaking, and the health of trafficked people in the UK. Health \& Human Rights, 13: 3.

Ottisova, L., Hemmings, S., Howard, L. M., Zimmerman, C., \& Oram, S. 2016. Prevalence and risk of violence and the mental, physical and sexual health problems associated with human trafficking: an updated systematic review. Epidemiology and Psychiatric Sciences, 25(4): 317-341.

Paharia, N., Kassam, K. S., Greene, J. D., \& Bazerman, M. H. 2009. Dirty work, clean hands: The moral psychology of indirect agency. Organizational Behavior and Human Decision Processes, 109(2): 134-141.

Peterson, C., \& Seligman, M. E. 1983. Learned helplessness and victimization. Journal of Social Issues, 39(2): 103-116.

Phung, K. 2018. Slavery and its links to organizations. In R. Burke \& C.L. Cooper (Eds.) Violence and abuse in and around organisations: 273-291. Abingdon, U.K.: Routledge.

Plambeck, E. L., \& Taylor, T. A. 2016. Supplier evasion of a buyer's audit: Implications for motivating supplier social and environmental responsibility. Manufacturing \& Service Operations Management, 18(2): 184-197.

Plummer, M., \& Cossins A. 2018. The cycle of abuse: When victims become offenders. Trauma, Violence, and Abuse, 19(3): 286-304.

Powell, E. E., \& Baker, T. 2017. In the beginning: Identity processes and organizing in multifounder nascent ventures. Academy of Management Journal, 60(6): 2381-2414.

Pratt, M.G., \& Rosa J.A. 2003. Transforming work-family conflict into commitment in network marketing organizations. Academy of Management Journal, 46(4): 395-418.

Quarantelli, E. L. 1954. The nature and conditions of panic. American Journal of Sociology, 60(3), 267-275.

Reid, J.A. 2016. Entrapment and enmeshment schemes used by sex traffickers. Sexual Abuse, 28(6): 491-511.

Reid, J.A., \& Jones S. 2011. Exploited vulnerability: Legal and psychological perspectives on child sex trafficking victims. Victims and Offenders, 6(2), 207-231.

Resick, C. J., Baltes, B. B., \& Shantz, C. W. 2007. Person-organization fit and work-related attitudes and decisions: Examining interactive effects with job fit and conscientiousness. Journal of Applied Psychology, 92(5): 1446-1455.

Ritchie, B. 1996. Compelled to crime: The gender entrapment of Black battered women. New York: NY: Routledge.

Rothwell, W. 2010. Effective succession planning: Ensuring leadership continuity and building talent from within. New York, N.Y.: Amacom.

Ryan, R. \& Deci E.L. 2006. Self-regulation and the problem of human autonomy: Does psychology need choice, self-determination, and will? Journal of Personality, 74(6): 1557-1586. 
Ryan, R.M., \& Deci E.L. 2000. Self-determination theory and the facilitation of intrinsic motivation, social development, and well-being. American Psychologist, 55(1): 68-78.

Schrempf-Stirling, J., Palazzo, G., \& Phillips, R. A. 2016. Historic corporate social responsibility. Academy of Management Review, 41(4): 700-719.

Sheldon, K.M., \& Elliot A.J. 1998. Not all personal goals are personal: Comparing autonomous and controlled reasons for goals as predictors of effort and attainment. Personality and Social Psychology Bulletin, 24(5): 546-557.

Shelley, L. 2010. Human trafficking: A global perspective. Cambridge, U.K.: Cambridge University Press.

Silverman, J. G., Decker, M. R., Gupta, J., Maheshwari, A., Willis, B. M., \& Raj, A. 2007. HIV prevalence and predictors of infection in sex-trafficked Nepalese girls and women. JAMA, 298(5): 536-542.

Singh, J., \& Agrawal, A. 2011. Recruiting for ideas: How firms exploit the prior inventions of new hires. Management Science, 57(1): 129-150.

Slade Shantz, A. F., Kistruck, G. M., Pacheco, D. F., \& Webb, J. W. 2020. How formal and informal hierarchies shape conflict within cooperatives: A field experiment in Ghana. Academy of Management Journal, 63(2): 503-529.

Spruce, H. 2017. Methods of human trafficking. https://www.highspeedtraining.co.uk/hub/methods-of-human-trafficking/

Stark, E. 2009. Coercive control: The entrapment of women in personal life. Oxford University Press.

State.gov. Report to Congress on 2021 trafficking in persons interim assessment pursuant to the trafficking victims protection act. https://www.state.gov/report-to-congress-on-2021trafficking-in-persons-interim-assessment-pursuant-to-the-trafficking-victims-protectionact/

Strike, V. M., \& Rerup, C. 2016. Mediated sensemaking. Academy of Management Journal, 59(3): 880-905.

Sturman, E. D. 2011. Involuntary subordination and its relation to personality, mood, and submissive behavior. Psychological Assessment, 23(1): 262-276.

Sweileh, W. M. 2018. Research trends on human trafficking: a bibliometric analysis using Scopus database. Globalization and Health, 14(1): 1-12.

Taylor, P.J., Wood A.M., Gooding P., Johnson, J., \& Tarrier N. 2009. Are defeat and entrapment best defined as a single construct? Personality and Individual Differences, 47(7): 795797.

Thompson, C.A., \& Prottas D.J. 2006. Relationships among organizational family support, job autonomy, perceived control, and employee well-being. Journal of Occupational Health Psychology, 11(1): 100-118.

Timmermans, S., \& Tavory I. 2012. Theory construction in qualitative research: From grounded theory to abductive analysis. Sociological Theory, 30(3): 167-186.

Tsoukas, H., \& Chia, R. 2002. On organizational becoming: Rethinking organizational change. Organization Science, 13(5): 567-582.

United Nations, 2000. Protocol to prevent, suppress and punish trafficking in persons, especially women and children, supplementing the United Nations Convention against transnational organized crime. Retrieved from http://www.uncjin.org/Documents/Conventions/dcatoc 
Van Buren III, H. J., Schrempf-Stirling, J., \& Westermann-Behaylo, M. 2021. Business and human trafficking: A social connection and political responsibility model. Business \& Society, 60(2): 341-375.

Van de Ven, A. H., \& Poole, M. S. 2005. Alternative approaches for studying organizational change. Organization Studies, 26(9): 1377-1404.

Vohs, K. D. 2013. The poor's poor mental power. Science, 341(6149): 969-970.

Wang, T., \& Zatzick, C. D. 2019. Human capital acquisition and organizational innovation: A temporal perspective. Academy of Management Journal, 62(1): 99-116.

Webb, J.W., Khoury T.A., \& Hitt M.A. 2019. The influence of formal and informal institutional voids on entrepreneurship. Entrepreneurship Theory and Practice, 44(3): 504-526.

Webb, J.W., Tihanyi L., Ireland R.D., \& Sirmon D.G. 2009. You say illegal, I say legitimate: Entrepreneurship in the informal economy. Academy of Management Review, 34(3): 492510.

Wee, E. X., Liao, H., Liu, D., \& Liu, J. 2017. Moving from abuse to reconciliation: A powerdependence perspective on when and how a follower can break the spiral of abuse. Academy of Management Journal, 60(6): 2352-2380.

Weick, K. E. 1979. The psychology of organizing, New York: Random House..

Weick, K. E. 1995. Sensemaking in organizations (Vol. 3). Thousand Oaks, CA: Sage Publications.

Weick, K. E., \& Sutcliffe, K. M. 2003. Hospitals as cultures of entrapment: a re-analysis of the Bristol Royal Infirmary. California Management Review, 45(2): 73-84.

Weitzer, R. 2015. Human trafficking and contemporary slavery. Annual Review of Sociology, 41: 223-242.

Weitzer, R. 2014. New directions in research on human trafficking. Annals of the American Academy of Political and Social Science, 653(1): 6-24.

Wilker, S., Kleim B., Geiling A., Pfeiffer A., Elbert T., \& Kolassa I.T. 2017. Mental defeat and cumulative trauma experiences predict trauma-related psychopathology: Evidence from a postconflict population in northern Uganda. Clinical Psychological Science, 5(6): 974984.

Wilson, K.L., \& Portes A. 1980. Immigrant enclaves: An analysis of the labor market experiences of Cubans in Miami. American Journal of Sociology, 86(2): 295-319.

Zhang, S.X. 2009. Beyond the 'Natasha' story-a review and critique of current research on sex trafficking. Global Crime, 10(3): 178-195.

Zimmerman, C., Hossain, M., \& Watts, C. 2011. Human trafficking and health: A conceptual model to inform policy, intervention and research. Social Science \& Medicine, 73(2): 327-335.

Zimmerman, C., \& Kiss, L. 2017. Human trafficking and exploitation: a global health concern. PLoS Medicine, 14(11): e1002437. 


\section{FOOTNOTES}

${ }^{1}$ We note that boys and men are trafficked into forced labor (primarily), including the sex industry, and are considered invisible victims because policies (and research) mostly focus on girls and women (Barron \& Frost, 2018; Hebert, 2016; Jones, 2010). We recognize that the findings of this study may not generalize to males, so it is our hope that future research also explores the plight of male exploitation in the sex industry.

${ }^{2}$ We assigned code names starting with "E" to denote people who now work to exploit girls and women and "S" to denote sex workers who are or were exploited in the sex industry. All study participants' code names have been changed and are unrelated to their real names. 
Table 1a

Descriptive Information of Workers in Sex Industry

\begin{tabular}{|c|c|c|}
\hline $\begin{array}{l}\text { Code } \\
\text { Name }\end{array}$ & Respondent information & Work experience \\
\hline Shanvi & $\begin{array}{l}\text { Age: } 30 \text { years; Gender: Female; Education: } \\
\text { Primary school; Family: Husband and two children; } \\
\text { Native region: Maharashtra }\end{array}$ & $\begin{array}{l}\text { Working status: Experienced; } \\
\text { Work experience: } 9 \text { years }\end{array}$ \\
\hline Sheza & $\begin{array}{l}\text { Age: } 42 \text { years; Gender: Female; Education: Not } \\
\text { educated; Family: Two nieces; Native region: } \\
\text { Karnataka }\end{array}$ & $\begin{array}{l}\text { Working status: Experienced; } \\
\text { Work experience: } 25 \text { years }\end{array}$ \\
\hline Shifa & $\begin{array}{l}\text { Age: } 41 \text { years; Gender: Female; Education: Not } \\
\text { educated; Family: Brothers and four children; } \\
\text { Native region: West Bengal }\end{array}$ & $\begin{array}{l}\text { Working status: Experienced; } \\
\text { Work experience: } 15 \text { years }\end{array}$ \\
\hline Saira & $\begin{array}{l}\text { Age: } 43 \text { years; Gender: Female; Education: } \\
\text { Primary school; Family: Husband and two children; } \\
\text { Native region: Maharashtra }\end{array}$ & $\begin{array}{l}\text { Working status: Experienced; } \\
\text { Work experience: } 13 \text { years }\end{array}$ \\
\hline Shichi & $\begin{array}{l}\text { Age: } 35 \text { years; Gender: Female; Education: Not } \\
\text { educated; Family: Husband and } 3 \text { children; Native } \\
\text { region: Maharashtra }\end{array}$ & $\begin{array}{l}\text { Working status: Experienced; } \\
\text { Work experience: } 15 \text { years }\end{array}$ \\
\hline Suvi & $\begin{array}{l}\text { Age: } 30 \text { years; Gender: Female; Education: Not } \\
\text { educated; Family: Two children; Native region: } \\
\text { Maharashtra }\end{array}$ & $\begin{array}{l}\text { Working status: Newly } \\
\text { recruited; Work experience: } 5 \\
\text { years }\end{array}$ \\
\hline Saaiqa & $\begin{array}{l}\text { Age: } 26 \text { years; Gender: Female; Education: } \\
\text { Primary school; Family: mother and brother; Native } \\
\text { region: West Bengal }\end{array}$ & $\begin{array}{l}\text { Working status: Newly } \\
\text { recruited; Work experience: } 5 \\
\text { years }\end{array}$ \\
\hline Seem & $\begin{array}{l}\text { Age: } 30 \text { years; Gender: Female; Education: } \\
\text { Primary school; Family: Brothers and his family; } \\
\text { Native region: Karnataka }\end{array}$ & $\begin{array}{l}\text { Working status: Experienced; } \\
\text { Work experience: } 10-11 \text { years }\end{array}$ \\
\hline Sriya & $\begin{array}{l}\text { Age: } 29 \text { years; Gender: Female; Education: Not } \\
\text { educated; Family: Mother, brother \& } 1 \text { child; Native } \\
\text { region: West Bengal }\end{array}$ & $\begin{array}{l}\text { Working status: Newly } \\
\text { recruited; Work experience: } 6- \\
7 \text { years }\end{array}$ \\
\hline Sannihitha & $\begin{array}{l}\text { Age: } 26 \text { years; Gender: Female; Education: } \\
\text { Primary; Family: Mother, brother and } 3 \text { sisters; } \\
\text { Native region: Maharashtra }\end{array}$ & $\begin{array}{l}\text { Working status: Newly } \\
\text { recruited; Work experience: } 3 \\
\text { years }\end{array}$ \\
\hline Saketha & $\begin{array}{l}\text { Age: } 31 \text { years; Gender: Female; Education: } \\
\text { Primary school; Family: Husband and two children; } \\
\text { Native region: Maharashtra }\end{array}$ & $\begin{array}{l}\text { Working status: Experienced; } \\
\text { Work experience: } 9 \text { years }\end{array}$ \\
\hline Saarya & $\begin{array}{l}\text { Age: } 32 \text { years; Gender: Female; Education: } \\
\text { Primary; Family: Parents, brothers, sisters \& } 2 \\
\text { children; Native region: W. Bengal }\end{array}$ & $\begin{array}{l}\text { Working status: Experienced; } \\
\text { Work experience: } 9 \text { years }\end{array}$ \\
\hline Sachchit & $\begin{array}{l}\text { Age: } 25 \text { years; Gender: Female; Education: } \\
\text { Primary school; Family: Mother and one child; } \\
\text { Native region: West Bengal }\end{array}$ & $\begin{array}{l}\text { Working status: Newly } \\
\text { recruited; Work experience: } 5 \text { - } \\
6 \text { years }\end{array}$ \\
\hline Stuthi & $\begin{array}{l}\text { Age: } 38 \text { years; Gender: Female; Education: Not } \\
\text { educated; Family: Two sisters; Native region: } \\
\text { Karnataka }\end{array}$ & $\begin{array}{l}\text { Working status: Experienced; } \\
\text { Work experience: } 20-25 \text { years }\end{array}$ \\
\hline
\end{tabular}




\begin{tabular}{|c|c|c|}
\hline Sajili & $\begin{array}{l}\text { Age: } 40 \text { years; Gender: Female; Education: } \\
\text { Primary; Family: Mother, father brother and sister; } \\
\text { Native region: Maharashtra }\end{array}$ & $\begin{array}{l}\text { Working status: Former or Ex- } \\
\text { worker; Work experience: } 12 \\
\text { years }\end{array}$ \\
\hline Sahasra & $\begin{array}{l}\text { Age: } 42 \text { years; Gender: Female; Education: } \\
\text { Primary; Family: Husband and five children; Native } \\
\text { region: Uttar Pradesh }\end{array}$ & $\begin{array}{l}\text { Working status: Former or Ex- } \\
\text { worker; Work experience: } \\
\text { Many years }\end{array}$ \\
\hline Sadhita & $\begin{array}{l}\text { Age: } 62 \text { years; Gender: Female; Education: Not; } \\
\text { Family: Son, daughter-in-law and grandchildren; } \\
\text { Native region: Karnatak }\end{array}$ & $\begin{array}{l}\text { Working status: Former or Ex- } \\
\text { worker; Work experience: } \\
\text { Many years }\end{array}$ \\
\hline Sria & $\begin{array}{l}\text { Age: } 42 \text { years; Gender: Female; Education: } \\
\text { Primary school; Family: Husband and one child; } \\
\text { Native region: Maharashtra }\end{array}$ & $\begin{array}{l}\text { Working status: Former or Ex- } \\
\text { worker; Work experience: } 9-11 \\
\text { years }\end{array}$ \\
\hline Sagarika & $\begin{array}{l}\text { Age: } 36 \text { years; Gender: Female; Education: Not } \\
\text { educated; Family: Parents and three brothers; } \\
\text { Native region: Karnataka }\end{array}$ & $\begin{array}{l}\text { Working status: Former or Ex- } \\
\text { worker; Work experience: } 8 \\
\text { years }\end{array}$ \\
\hline Siny & $\begin{array}{l}\text { Age: } 40 \text { years; Gender: Female; Education: Not } \\
\text { educated; Family: Children and grandchildren; } \\
\text { Native region: Karnataka }\end{array}$ & $\begin{array}{l}\text { Working status: Former or Ex- } \\
\text { worker; Work experience: } 14 \\
\text { years }\end{array}$ \\
\hline Sonika & $\begin{array}{l}\text { Age: } 38 \text { years; Gender: Female; Education: Not } \\
\text { educated; Family: Husband and children; Native } \\
\text { region: Maharashtra }\end{array}$ & $\begin{array}{l}\text { Working status: Former or Ex- } \\
\text { worker; Work experience: } 7 \\
\text { years }\end{array}$ \\
\hline Sruthi & $\begin{array}{l}\text { Age: } 38 \text { years; Gender: Female; Education: } \\
\text { Primary; Family: Parents, brother and sister; Native } \\
\text { region: Uttar Pradesh }\end{array}$ & $\begin{array}{l}\text { Working status: Former or Ex- } \\
\text { worker; Work experience: } 10 \\
\text { years }\end{array}$ \\
\hline Sudakshima & $\begin{array}{l}\text { Age: } 45 \text { years; Gender: Female; Education: } \\
\text { Primary education; Family: None; Native region: } \\
\text { Maharashtra }\end{array}$ & $\begin{array}{l}\text { Working status: Former or Ex- } \\
\text { worker; Work experience: } 14 \\
\text { years }\end{array}$ \\
\hline
\end{tabular}


Table 1b

Descriptive Information of Exploiters

\begin{tabular}{|c|c|c|}
\hline $\begin{array}{l}\text { Code } \\
\text { Name }\end{array}$ & Respondent information & Work experience \\
\hline Ekanga & $\begin{array}{l}\text { Age: Not disclose; Gender: Male; Education: } \\
\text { Primary school; Family: Wife and two children; } \\
\text { Native region: Jharkhand }\end{array}$ & $\begin{array}{l}\text { Working responsibility: Recruiting } \\
\text { girls; Working location: Brothel; } \\
\text { Work experience: } 4 \text { years }\end{array}$ \\
\hline Eha & $\begin{array}{l}\text { Age: } 47 \text { years; Gender: Male; Education: Not } \\
\text { educated; Family: Mother, wife and three } \\
\text { children; Native region: West Bengal }\end{array}$ & $\begin{array}{l}\text { Working responsibility: Run } \\
\text { brothel; Working location: Brothel; } \\
\text { Work experience: } 15 \text { years }\end{array}$ \\
\hline Earaja & $\begin{array}{l}\text { Age: } 45 \text { years; Gender: Male; Education: Not } \\
\text { educated; Family: Parents and brothers; Native } \\
\text { region: Assam }\end{array}$ & $\begin{array}{l}\text { Working responsibility: Manage } \\
\text { girls; Working location: Brothel; } \\
\text { Work experience: } 21 \text { years }\end{array}$ \\
\hline Elisha & $\begin{array}{l}\text { Age: } 36 \text { years; Gender: Female; Education: } \\
\text { Primary school; Family: Mother, brother and } \\
\text { sisters; Native region: Maharashtra }\end{array}$ & $\begin{array}{l}\text { Working responsibility: Run } \\
\text { brothel; Working location: Brothel; } \\
\text { Work experience: } 3 \text { years }\end{array}$ \\
\hline Eilin & $\begin{array}{l}\text { Age: } 35 \text { years; Gender: Female; Education: } \\
\text { Primary education; Family: One child; Native } \\
\text { region: Maharashtra }\end{array}$ & $\begin{array}{l}\text { Working responsibility: Manage } \\
\text { girls; Working location: Brothel; } \\
\text { Work experience: } 6 \text { years }\end{array}$ \\
\hline Eshika & $\begin{array}{l}\text { Age: } 37 \text { years; Gender: Female; Education: } \\
\text { Not educated; Family: Children; Native region: } \\
\text { Maharashtra }\end{array}$ & $\begin{array}{l}\text { Working responsibility: Run } \\
\text { brothel; Working location: Brothel; } \\
\text { Work experience: } 5-7 \text { years }\end{array}$ \\
\hline Ekaa & $\begin{array}{l}\text { Age: } 45 \text { years; Gender: Female; Education: } \\
\text { Not educated; Family: None; Native region: } \\
\text { Karnataka }\end{array}$ & $\begin{array}{l}\text { Working responsibility Recruiting } \\
\text { girls; Working location: Brothel; } \\
\text { Work experience: } 10 \text { years }\end{array}$ \\
\hline Evani & $\begin{array}{l}\text { Age: } 50+\text { years; Gender: Female; Education: } \\
\text { Not educated; Family: Brothers and his family; } \\
\text { Native region: Chhattisgarh }\end{array}$ & $\begin{array}{l}\text { Working responsibility Run brothel } \\
\text { Working location: Street and } \\
\text { brothel; Work experience: } 20+ \\
\text { years }\end{array}$ \\
\hline Eerav & $\begin{array}{l}\text { Age: Not disclosed; Gender: Male; Education: } \\
\text { Not educated; Family: None; Native region: } \\
\text { Maharashtra }\end{array}$ & $\begin{array}{l}\text { Working responsibility: Manage } \\
\text { girls; Working location: Street; } \\
\text { Work experience: } 5 \text { years }\end{array}$ \\
\hline Ednit & $\begin{array}{l}\text { Age: } 50 \text { years. Gender: Male; Education: Not } \\
\text { educated; Family: Not disclosed; Native } \\
\text { region: Maharashtra }\end{array}$ & $\begin{array}{l}\text { Working responsibility: Recruiting } \\
\text { girls; Working location: Brothel; } \\
\text { Work experience: } 30 \text { years }\end{array}$ \\
\hline Ekaja & $\begin{array}{l}\text { Age: } 38 \text { years; Gender: Female; Education: } \\
\text { Not educated; Family: Not disclosed; Native } \\
\text { region: Telangana }\end{array}$ & $\begin{array}{l}\text { Working responsibility: Run } \\
\text { brothel; Working location: Brothel; } \\
\text { Work experience: } 8 \text { years }\end{array}$ \\
\hline Ekaparnika & $\begin{array}{l}\text { Age: } 45 \text { years; Gender: Female; Education: } \\
\text { Primary education; Family: Husband and three } \\
\text { children; Native region: Maharashtra }\end{array}$ & $\begin{array}{l}\text { Working responsibility: Run } \\
\text { brothel; Working location: Brothel; } \\
\text { Work experience: } 9 \text { years }\end{array}$ \\
\hline
\end{tabular}




\section{Table 2}

\section{Deceptive Recruiting of the Vulnerable}

\begin{tabular}{|c|c|}
\hline Vulnerability & $\begin{array}{l}\text { "The situation of their home is not good. They don't have members of their house earning an } \\
\text { income" (Udaan, NGO). } \\
\text { "I earned so much I got my two sisters married" (Ekaja, Ex-sex worker) } \\
\text { "There were a lot of problems at home and that is why I decided [to enter prostitution]. In a } \\
\text { day if I take home } 5,000 \text { rupees things can happen and my sister can study and I can get my } \\
\text { dad his medicines. ... I could get my dad's treatment done without begging for money. So I } \\
\text { felt this [working in prostitution] was right for me" (Sruthi, Ex-sex worker). } \\
\text { "Some are helpless. They want to support their family. Some come here and they have no } \\
\text { options for the future so they are here" (Eshika, Sex trafficking entrepreneur). } \\
\text { "When I used to do household work there were a lot of problems- there was no food to eat, } \\
\text { kids had problems [because] had to study in the municipality [school]. If we worked as } \\
\text { housemaids, we only get } 500 \text { rupees/month only. That used to go in the room rent. I could } \\
\text { not ask my husband for anything because he used to drink and then hit me. I couldn't leave } \\
\text { him and go [i.e., get divorced], so I had to do this" (Sannihitha, Newly recruited sex worker). } \\
\text { "I mean, the roots of this [prostitution work] is poverty. And poverty, you know, people are } \\
\text { vulnerable and open to exploitation and so it is an economic situation" (Freeset, NGO). }\end{array}$ \\
\hline & $\begin{array}{l}\text { "In some cases it is the mother also. You interview of a girl named Shifa, her mother got her } \\
\text { married at a very young age and her husband sold her here" (Sai, NGO). } \\
\text { "Husbands leave them [their wives] in the city. [The husbands] take all the money [that the } \\
\text { wife earns]. He only gives her money for the household expenses and the rest he keeps for } \\
\text { himself and puts in the bank" (Earaja, Sex trafficking entrepreneur). } \\
\text { "Respondent: I think these girls come from very poor families. ... and sometimes girls are } \\
\text { married off at a young age and then their husbands are old and these girls are forced into } \\
\text { prostitution. If you see the guys who come to sell off these girls they are more than } 40 \text { years } \\
\text { old and the girls are } 30 \text { - } 32 \text { years old. Their marriage was a child marriage. Interviewer: } \\
\text { These girls are bought by their husbands and the husband's family? Respondent: yes. } \\
\text { (Earaja, Sex trafficking entrepreneur) }\end{array}$ \\
\hline & $\begin{array}{l}\text { "Her mother died and father married again. Her step mother was troubling her and father } \\
\text { was not aware of this and she [the step mother] brought her to Mumbai and sold her [to the } \\
\text { brothel owner]" (Aadhar Trust, NGO) } \\
\text { "Interviewer: These parents who say "take my girl", do they know what kind of work the girl } \\
\text { will do? Middleman: They get the girl here [the city] saying to the family that the girl will do } \\
\text { household chores and work. They don't talk the truth. No one [members of the family who } \\
\text { have sold their female members] insults each other, even though they know they [the girls and } \\
\text { women who were sold] are not doing good work. Some say they are working in the hotel line, } \\
\text { some say they do household chores" (Ednit, Sex trafficking entrepreneur). } \\
\text { "The girls I used to see in that house, when I spoke to them, I came to know that they were } \\
\text { also bought like me and then pushed in this profession. They said papa had signed a contract } \\
\text { with them. ... one of the girl's family story was like mine. [A family member told her] you } \\
\text { don't have any option, you need to do this work in Ghar Kaam. She [the brothel madam] will } \\
\text { not give you money. At the start you will not like it [the prostitution work], then you will get } \\
\text { use to it" (Sruthi, Ex-sex worker). } \\
\text { "There's a whole lot of different ways that women get into prostitution. Generally, the root } \\
\text { and the foundation of it is, it begins with poverty and vulnerability. And then there are } \\
\text { people that exploit them. I thought at the beginning it was people stealing little girls on their } \\
\text { way home from school, something like that. Although it does go on, the reality is, } \\
\text { particularly in this part of the world, you know, the traffickers are neighbours and friends } \\
\text { and mothers and fathers and aunties and uncles. For generation upon generation, a daughter }\end{array}$ \\
\hline
\end{tabular}




\begin{tabular}{|c|c|}
\hline & $\begin{array}{l}\text { is placed or put into prostitution so the money can go back to the village so the family } \\
\text { survives. There is a little shame [felt by the family] attached to that [selling a female family } \\
\text { member]. Nobody talks about it, that it's been going on for generations. If you go to the } \\
\text { village and say: "Does trafficking happen here?" They say: "It doesn't happen here, it } \\
\text { happens in the next village". So, you go to the other village and they say: "It doesn't happen } \\
\text { here, it happens in the village that you just came from." So, they're all ashamed. .. I was } \\
\text { with a woman today, just a few hours ago, that actually did that-she put her own daughter } \\
\text { in prostitution because they had bills to pay, medical bills for her husband. And so, the } \\
\text { daughter was sacrificed. ... it actually becomes the norm, it becomes what you do. The way } \\
\text { you think, the way you understand. And women go into prostitution, knowing they have a } \\
\text { responsibility to support the family. Sometimes they are not welcome back home, their } \\
\text { money is welcome, but they are not" (Freeset, NGO). }\end{array}$ \\
\hline & 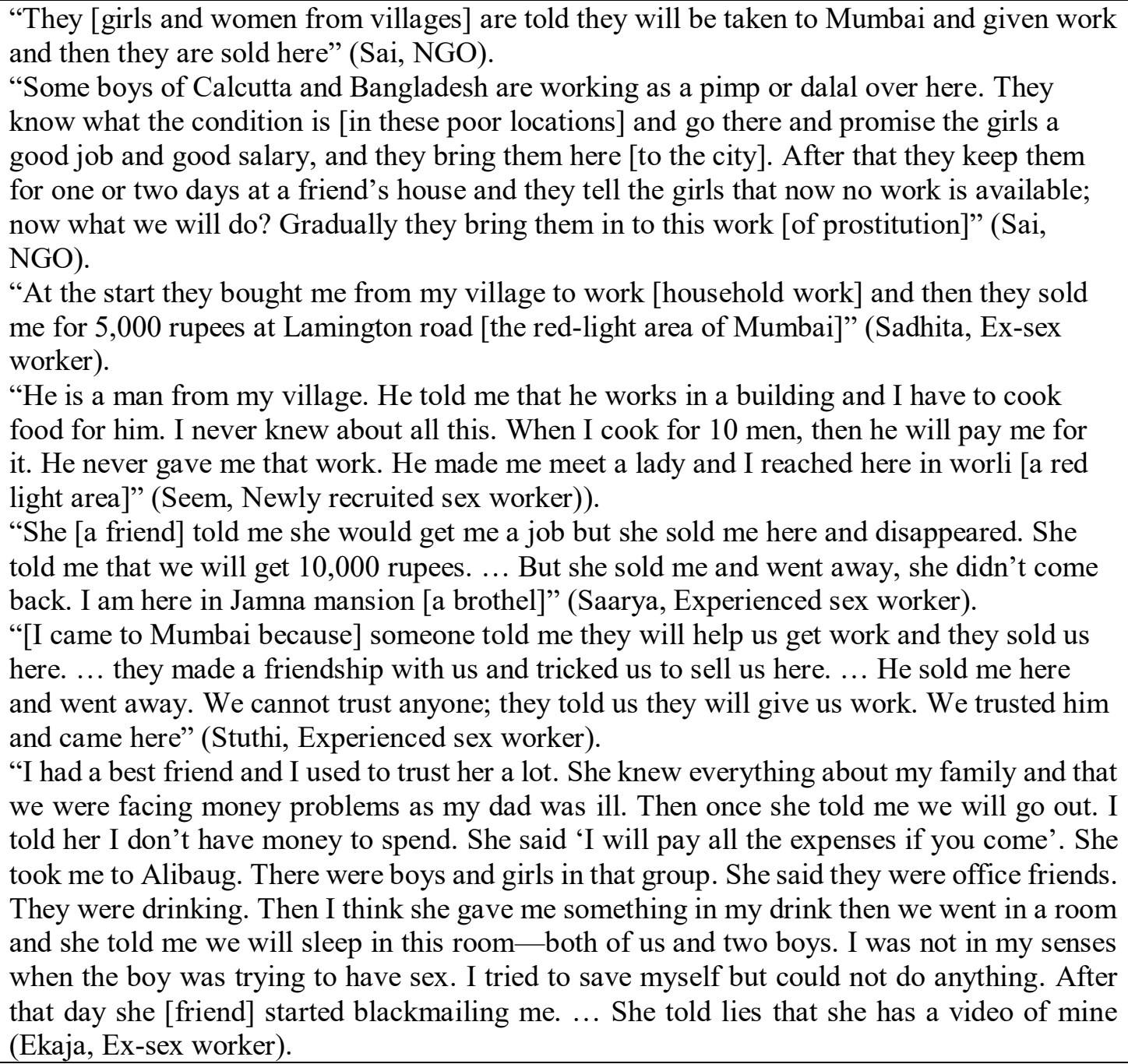 \\
\hline
\end{tabular}




\section{Table 3}

\section{Entrapping through Isolation}

\begin{tabular}{|c|c|}
\hline $\begin{array}{l}\text { Physical } \\
\text { domination }\end{array}$ & $\begin{array}{l}\text { "There are mostly girls from Bangladesh and Nepal. ... They bring the girls of } \\
\text { those families and sell them here [to the city brothel]. The girls that don't agree } \\
\text { and are black mailed that their family will be killed [if they do not work in } \\
\text { prostitution] (Aadhar Trust, NGO). } \\
\text { First time when I ran [away from the brothel] I did not know what will happen } \\
\text { to me if I was caught. ... But when we were caught we were harassed so } \\
\text { brutally. Still I tried to run again. They inserted a rod in my behind so that } \\
\text { blood use to come out. Still I tried [to escape]. But they closed me in a room } \\
\text { with eight boys who had sex with me day and night and I was naked there all } \\
\text { the time. That time I gave up and decided to stay here only" (Suvi, Ex-sex } \\
\text { worker). } \\
\text { "She refused to work/entertain customers for quite some time. She was very } \\
\text { badly treated, experienced starvation etc., and ultimately gave up" (Sahasra, } \\
\text { Ex-sex worker, Field notes) } \\
\text { "They told me that they had bought me here to have sex with men. I said I } \\
\text { wouldn't do it, and asked to be put on the train home. They beat me severely. } \\
\text { After beating me severely the lady left me and held both my arms and her } \\
\text { daughter held down my legs and the customer forced himself on me. For } \\
\text { three months I was in JJ hospital. Three months" (Sruthi, Sex worker) }\end{array}$ \\
\hline $\begin{array}{l}\text { Social } \\
\text { isolation and } \\
\text { reality } \\
\text { disconnection }\end{array}$ & $\begin{array}{l}\text { "They use to give some medicine to every girl. I use to not take it. Because I } \\
\text { started understanding. They use to give every new girl some medicine to } \\
\text { take" (Sahasra, Ex-sex worker). } \\
\text { "I came to Mumbai; and slowly, slowly started getting conscious. I saw the } \\
\text { [sign] boards. Why have I come to Mambai and I asked the aunty. Aunty said } \\
\text { we have come for some work. I will take you to a house for a week to say and } \\
\text { then take you back. Saying this she left me there. Then lalita aunty who was } \\
\text { there hit me forcibly. She told me, you have to do this work. You cannot go } \\
\text { back alive, you will be killed. You have to do this work and she beat me and } \\
\text { beat me more. After doing this she got me to do the work" (Saketha, } \\
\text { Experienced Sex worker) }\end{array}$ \\
\hline Contamination & $\begin{array}{l}\text { "Now you can't go back to your village. They [villagers or family] will kill } \\
\text { you. Now I don't know what to do. I knew my grandfather was very strict } \\
\text { and he will kill me" (Sria, Ex-sex worker). } \\
\text { "I know lots of girls that are not welcome [back in their village] because if } \\
\text { they come home and people know, then the family gets the shame for } \\
\text { hanging around them. So, a bit of out of sight out of mind. They send the } \\
\text { money, but can't come back themselves" (Freeset, NGO). }\end{array}$ \\
\hline
\end{tabular}


Table 4: Extinguishing Alternatives by Building Barriers

\begin{tabular}{|c|c|}
\hline Indebtedness & $\begin{array}{l}\text { "There was a boy who was } 25 \text { years old. I told him that you are so small and you } \\
\text { come to me everyday. He said that I like you. ... He said will you marry me. I } \\
\text { told him that your parents won't agree no-one would make someone who works } \\
\text { in prostitution her daughter-in -aw. He said that for you, I am ready to leave my } \\
\text { parents as well. But at that time, I did not like any men. He was the only guy } \\
\text { who use to come to meet me and not sleep with me. He did not want sex all the } \\
\text { time. Gradually we got into a relationship. ... When I told my madam that I want } \\
\text { to get married. ... She said he will have to give a big amount on behalf of you } \\
\ldots \text { She told him that he will have to give her } 10 \text { lakh if he wants to get married } \\
\text { to me. ... Then he told me that you should try and run since you go out now. I } \\
\text { told him that they have a big gang they will catch me and pull me back. ... } \\
\text { Negotiate with them. Finally, they agreed at } 5 \text { lakh. He gave them } 5 \text { lakhs and } \\
\text { then I never looked back and we don't talk about it" (Sudakshima, Ex-Sex } \\
\text { worker). }\end{array}$ \\
\hline & $\begin{array}{l}\text { "As of now she is in this profession [prostitution], then, where will she go if she } \\
\text { is not from Mumbai. She has only seen one brothel and she goes to another } \\
\text { brothel in a car. She does not know anything around. Where will she go?" } \\
\text { (Aadhar Trust, NGO). } \\
\text { "... and the girl does not know anything about this because she is uneducated } \\
\text { and she has no idea how to get back to her home. All the doors are closed for } \\
\text { her once she is in a brothel" (Sai, NGO). } \\
\text { "We used to never go out; either stay at home [the brothel] or with a customer. } \\
\text { If we had to buy clothes, she [the madam of the brothel] used to come with us. } \\
\text { She used to not give us money in hand. ... All make up commodities, she used } \\
\text { to get for us" (Ekaja, Ex-sex worker) } \\
\text { "Some people must have betrayed them [the girls and women working in } \\
\text { prostitution] ... [they] do not trust people easily. They use to say to us [NGO } \\
\text { workers] that there are many people like you that come to us and then betray } \\
\text { us. So they use to not trust us. So we use to convince them that we are from an } \\
\text { NGO and this is for your betterment-your future will improve. In the future } \\
\text { we can help you if you have any issues. We are here to help you. After that } \\
\text { they started trusting us" (Sai, NGO) "Yes, I went away [left the brothel]. But } \\
\text { the guy left me and ran away, so I had to return here [to the brothel]" (Saarya, } \\
\text { Experienced sex worker). } \\
\text { "The women didn't trust us at the beginning. They told us that we would have } \\
\text { to earn their trust and we took that very seriously. And thankfully their trust } \\
\text { came quickly from their side which we really appreciate. But it was something } \\
\text { that needed to be given from them" (Freeset, NGO). }\end{array}$ \\
\hline
\end{tabular}




\section{Figure 1}

\section{Data Structure}

\section{First-Order Codes}

- Little to household income

- Outstanding medical bills and need for dowry

- Support children's housing food, education

- Married at young age to older man who sells her

- Husband not earning and requires wife to enter prostitution to provide for him

- Family paid by an agent to find the girl "work"

- The nature of the work remains unspoken of

- More distant relatives sell the girl to middleman

- Told to come to the city for a good jobhousehold work

- Told by boyfriend to runaway together-for love

- Torture such as physical beatings and denied food

- Rape

- Threat of killing family

- Locked in a room for extended periods

- Restricted movement-within building

- Threatened that family will be told of the work

- Medicine to put on weight

- Plied with alcohol

- Inject with drugs to make the women feel numb

- Family stigmatizes member engaged in that work

- Family is stigmatized by their member's work

- The woman is stigmatized by society

- Woman has to payback her "sale price"

- Provided loans with high interest rates

- Had to pay for normal items

- Tricked into profession; unwilling to trust again

- Only contact is with those in the "system"

- Find it difficult to trust people

- As sex worker learned how to run a brothel

- Understood how to engage customers

- Social capital in the sex industry

- Can recognize vulnerable girls and women

- Knowledge of different deceptive tactics

- Strong connections within sex industry
Second-Order Themes

\section{Overarching}

Dimensions
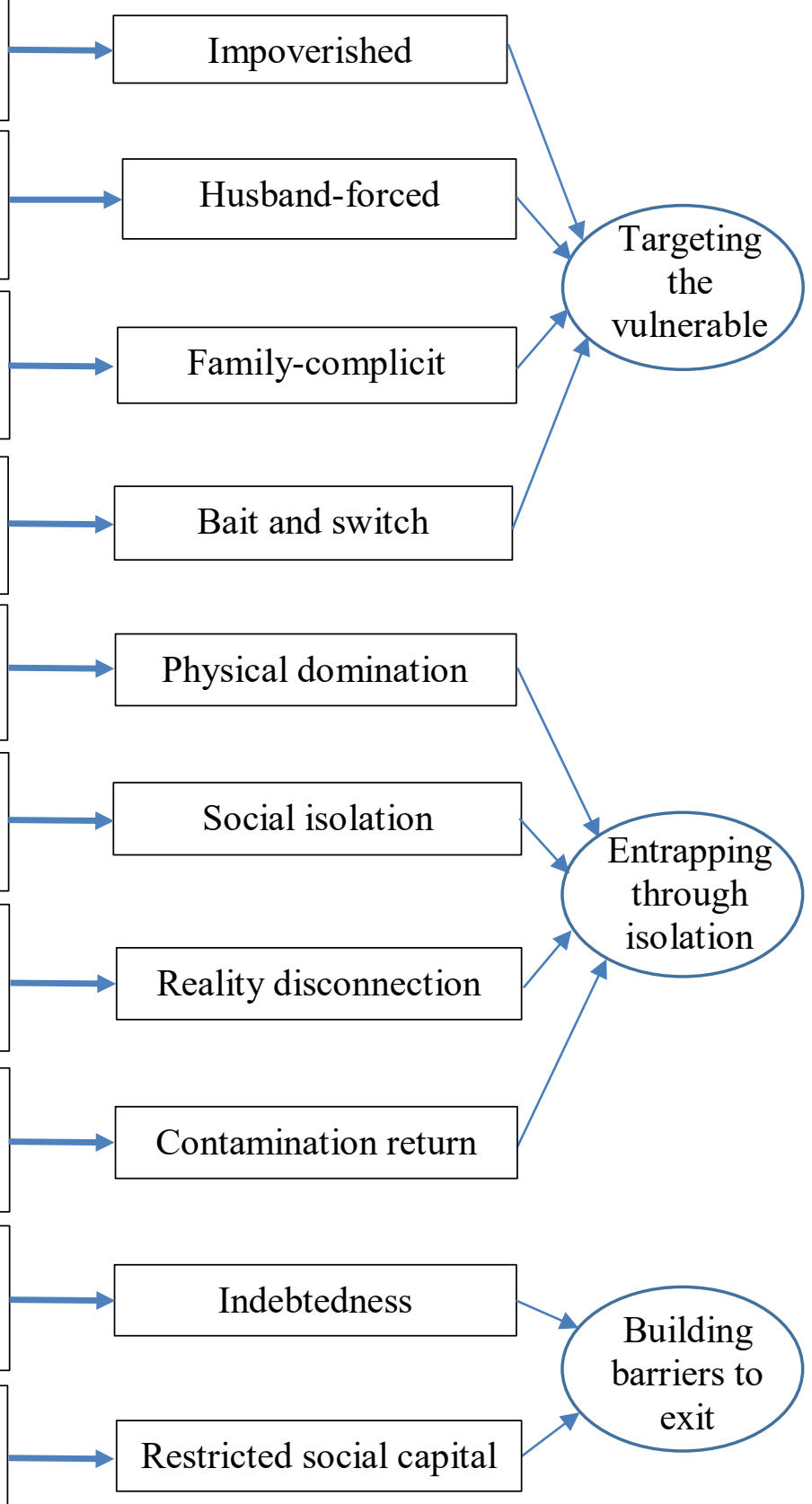

barriers to

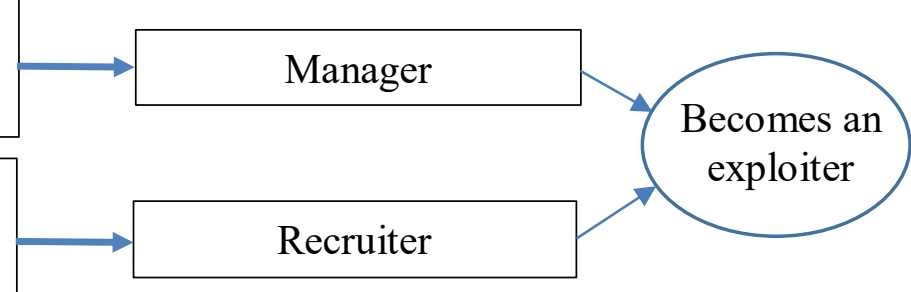




\section{Figure 2}

Organizing the Exploitation of Vulnerable Individuals for Labor

Targeting vulnerable populations
Deceptive recruiting of the vulnerable

- Build then break trust

- Bait and switch

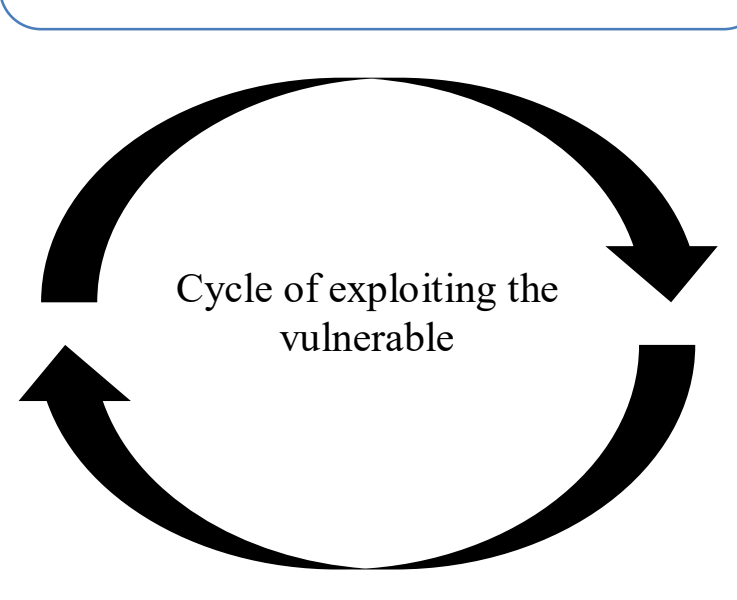

Entrapping through isolation

- Physical domination

- Isolation \&

contamination

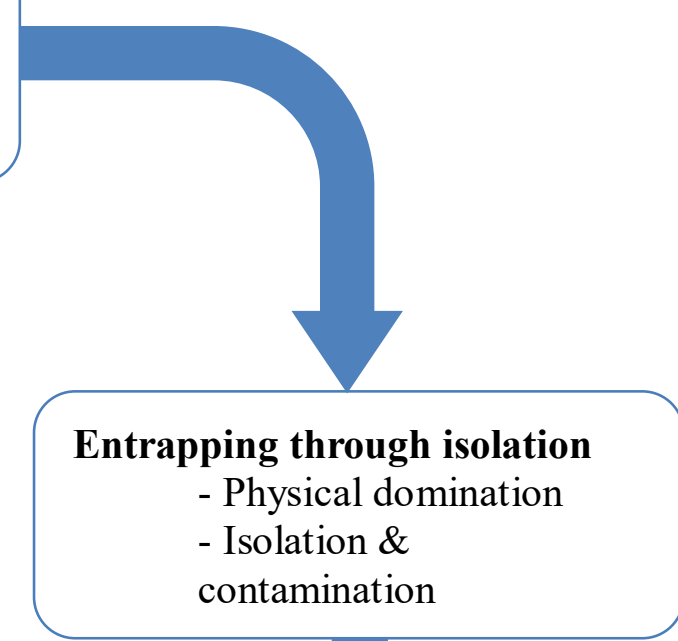

responsibility

- Recruiters of new workers

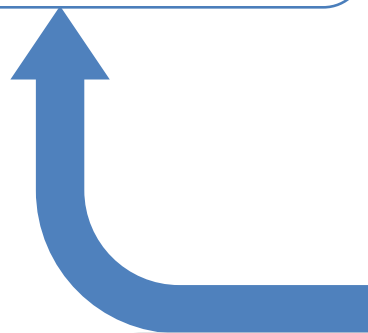

\section{barriers}

- Indebtedness

- Limited network

\section{Escape}


